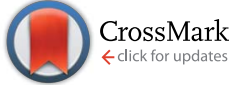

Cite this: RSC Adv., 2016, 6, 66990

\title{
Enhanced oxidative and adsorptive capability towards antimony by copper-doping into magnetite magnetic particles $\uparrow$
}

\author{
Zenglu Qi, ${ }^{\text {ab }}$ Huachun Lan, ${ }^{a}$ Tista Prasai Joshi, ${ }^{\text {ab }}$ Ruiping Liu, ${ }^{\text {*a }}$ Huijuan Liu ${ }^{a}$ \\ and Jiuhui $\mathrm{Qu}^{\mathrm{a}}$
}

This study compared the removal capability and mechanisms involved in the removal of aqueous Sb by non-doped and $\mathrm{Cu}$-doped $\mathrm{Fe}_{3} \mathrm{O}_{4}$ (magnetite). After doping $\mathrm{Cu}$ into $\mathrm{Fe}_{3} \mathrm{O}_{4}$, it exhibited a smaller particle size with slightly declined saturation magnetization, and enhanced antimony adsorptive capability. Nondoped $\mathrm{Fe}_{3} \mathrm{O}_{4}$ showed a maximum adsorption capacity $\left(Q_{\max }\right)$ of $34.46 \mathrm{mg} \mathrm{Sb}(\mathrm{III}) \mathrm{g}^{-1}$ and $7.07 \mathrm{mg} \mathrm{Sb}(\mathrm{v})$

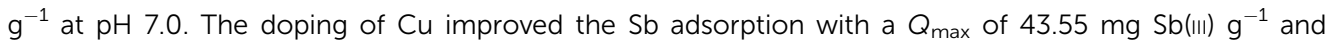
$30.92 \mathrm{mg} \mathrm{Sb}(\mathrm{v}) \mathrm{g}^{-1}$ accordingly. The co-existing sulfate and carbonate had a negligible effect on $\mathrm{Sb}$ removal; however, phosphate at $10 \mathrm{mM}$ decreased the $\mathrm{Sb}(\mathrm{II})$ and $\mathrm{Sb}(\mathrm{V})$ removal by $50.1 \%$ and $18.2 \%$ for $\mathrm{Fe}_{3} \mathrm{O}_{4}$ and by $14.1 \%$ and $58.6 \%$ for $\mathrm{Cu}$-doped $\mathrm{Fe}_{3} \mathrm{O}_{4}$. As for $\mathrm{Cu}$-doped $\mathrm{Fe}_{3} \mathrm{O}_{4}$, the results indicated that the $\mathrm{Sb}(\mathrm{II})$ oxidation on $\equiv \mathrm{Cu}^{\prime \prime}-\mathrm{O}$ sites was much more significant than that on $\equiv \mathrm{Fe}^{\prime \prime \prime}-\mathrm{O}$ sites and the dissolution oxygen amount did not affect this process. Upon the electron transfer from $\mathrm{Sb}\left({ }_{11}\right)$ to $\mathrm{Cu}\left({ }^{\prime \prime}\right)$, the formed $\mathrm{Cu}(\mathrm{I})$ and $\mathrm{Sb}(\mathrm{V})$ tends to release into the solution and the $\mathrm{Cu}(\mathrm{I})$ disproportionates to give $\mathrm{Cu}(\|)$ ions and a precipitate of $\mathrm{Cu}(0)$ thereafter. The magnetic $\mathrm{Cu}$-doped $\mathrm{Fe}_{3} \mathrm{O}_{4}$ shows good removal efficiency towards both $\mathrm{Sb}(\mathrm{III})$ and $\mathrm{Sb}(\mathrm{V})$ and is a potential adsorbent for $\mathrm{Sb}$ removal in practice.

Received 24th May 2016

Accepted 8th July 2016

DOI: 10.1039/c6ra13412b

www.rsc.org/advances
So far, many techniques such as coagulation and flocculation, ${ }^{5}$ reverse osmosis, ${ }^{6}$ electrochemical process, ${ }^{7}$ and adsorption $^{\mathbf{8}, 9}$ have been proposed for $\mathrm{Sb}$ removal. Among these methods, adsorption is advantageous with high efficiency, lowcost, and low maintenance requirement. It is widely considered as one of the best available technologies for medium- and smallscale systems. ${ }^{10}$ Conventional adsorbents such as activated carbon, ${ }^{11}$ aluminum-based adsorbent, ${ }^{12}$ and iron-based adsorbent ${ }^{13}$ have been developed for $\mathrm{Sb}$ adsorption. However, their adsorptive capacity is not as high as expected, and the high operating costs of solid-liquid separation process which hinders their large-scale applications.

Recently, magnetic particles, as a new kind of adsorbent attracted worldwide attention due to their exhibited excellent adsorption performance and low-cost magnetic solid-liquid separation in the water purification. ${ }^{\mathbf{1 4 , 1 5}}$ Over the past decade, the novel magnetic adsorbents, e.g. $\mathrm{MnO}_{2}$ modified graphene oxide nanocomposite, ${ }^{16} \gamma-\mathrm{Fe}_{2} \mathrm{O}_{3},{ }^{5}$ magnetite $\left(\mathrm{Fe}_{3} \mathrm{O}_{4}\right),{ }^{6}$ and nanoscale zero-valent iron (nZVI), ${ }^{17}$ have been developed for removal of various pollutants from water. Pure $\mathrm{Fe}_{3} \mathrm{O}_{4}$ shows excellent magnetic properties; however, its adsorption efficiency towards $\mathrm{Sb}$ is relatively low. ${ }^{\mathbf{1 8 , 1 9}}$ The doping of transition metal elements like zinc, ${ }^{20}$ cobalt, ${ }^{21}$ copper, ${ }^{22}$ manganese ${ }^{23}$ into $\mathrm{Fe}_{3} \mathrm{O}_{4}$ increases its surface sites available for adsorption, and the adsorption capability may be improved accordingly. ${ }^{24}$ For example, the doping of copper $(\mathrm{Cu})$ into $\mathrm{Fe}_{3} \mathrm{O}_{4}$ increases the adsorption sites and improved its adsorption towards arsenic. ${ }^{25}$ Furthermore, 
Wang et al. found that $\mathrm{As}(\mathrm{III})$ was efficiently oxidized to $\mathrm{As}(\mathrm{v})$ by $\mathrm{O}_{2}$ on $\mathrm{Fe}_{3} \mathrm{O}_{4}: \mathrm{Cu}$ particles, and the $\mathrm{Cu}$ (II)/(I) couple was proposed to play a dominant role. ${ }^{26}$ Unfortunately, there is lack of direct evidence that $\mathrm{Cu}$-doped $\mathrm{Fe}_{3} \mathrm{O}_{4}$ owes enhanced catalytic effect on adsorption or oxidation of $\mathrm{Sb}$. From the thermodynamics pointof-view, $\mathrm{Cu}$-doped $\mathrm{Fe}_{3} \mathrm{O}_{4}$ may also act as an electronic mediation center to accelerate the oxidation of aqueous $\mathrm{Sb}$ (III). This effect may play an important role with respect to the adsorption of reductive species. However, previous studies have rarely focused on application of $\mathrm{Cu}$-doped $\mathrm{Fe}_{3} \mathrm{O}_{4}$ for removal of $\mathrm{Sb}(\mathrm{III})$ and $\mathrm{Sb}$ (v) from drinking water.

In the present work, we prepared two magnetic samples of non-doped $\mathrm{Fe}_{3} \mathrm{O}_{4}$ and $\mathrm{Cu}$-doped $\mathrm{Fe}_{3} \mathrm{O}_{4}$ by solvothermal method, and compared their magnetic properties and surface characters. The adsorptive behaviors of non-doped $\mathrm{Fe}_{3} \mathrm{O}_{4}$ and $\mathrm{Cu}$-doped $\mathrm{Fe}_{3} \mathrm{O}_{4}$ towards $\mathrm{Sb}(\mathrm{III})$ and $\mathrm{Sb}(\mathrm{v})$ as well as the effects of $\mathrm{pH}$, ionic strength, and coexisting anions on adsorption were investigated in batch experiments. Furthermore, the species transformation of $\mathrm{Sb}$ and $\mathrm{Cu}$ during adsorption of $\mathrm{Sb}$ (III) onto $\mathrm{Cu}$-doped $\mathrm{Fe}_{3} \mathrm{O}_{4}$ in $\mathrm{N}_{2}$ or $\mathrm{O}_{2}$-purging systems were analyzed, and the mechanisms and possible pathways involve in were proposed accordingly.

\section{Experimental}

\subsection{Chemicals}

All of the chemical reagents used in this study, including iron(III) chloride hexahydrate $\left(\mathrm{FeCl}_{3} \cdot 6 \mathrm{H}_{2} \mathrm{O}\right)$, copper(II) chloride dehydrate $\left(\mathrm{CuCl}_{2} \cdot 2 \mathrm{H}_{2} \mathrm{O}\right)$, ethylene glycol $\left(\mathrm{C}_{2} \mathrm{H}_{6} \mathrm{O}_{2}\right)$, sodium acetate $\left(\mathrm{C}_{2} \mathrm{H}_{3} \mathrm{NaO}_{2}\right)$, polyethylene glycol $\left(\mathrm{H}\left(\mathrm{OCH}_{2} \mathrm{CH}_{2}\right)_{\mathrm{n}} \mathrm{OH}\right)$, unless otherwise noted, were analytical grade and purchased from Sinopharm Chemical Reagent Co. Ltd, China.

The $\mathrm{Sb}(\mathrm{III})$ and $\mathrm{Sb}(\mathrm{v})$ stock solutions $\left(100 \mathrm{mg} \mathrm{L}^{-1}\right)$ were prepared by dissolving the antimony potassium tartrate $\left(\mathrm{C}_{4^{-}}\right.$$\left.\mathrm{H}_{4} \mathrm{KO}_{7} \mathrm{Sb} \cdot 0.5 \mathrm{H}_{2} \mathrm{O}\right)$ and potassium pyroantimonate $\left(\mathrm{KSb}(\mathrm{OH})_{6}\right)$ (Sigma-Aldrich Co. Ltd, USA) with ultrapure water (Millipore, 18.2 M ..cm resistivity), respectively.

\subsection{Adsorbents preparation}

According to a modified version of the procedure of Deng, ${ }^{27}$ the non-doped $\mathrm{Fe}_{3} \mathrm{O}_{4}$ and $\mathrm{Cu}$-doped $\mathrm{Fe}_{3} \mathrm{O}_{4}$ magnetic nanoparticles were prepared by solvothermal method. Briefly, while preparing $\mathrm{Cu}$-doped $\mathrm{Fe}_{3} \mathrm{O}_{4}$, an amount of $1.08 \mathrm{~g} \mathrm{FeCl}_{3} \cdot 6 \mathrm{H}_{2} \mathrm{O}$ and $1.71 \mathrm{~g}$ $\mathrm{CuCl}_{2} \cdot 2 \mathrm{H}_{2} \mathrm{O}$ were dissolved in $80 \mathrm{~mL}$ ethylene glycol, and the solution was stirred at room temperature for $30 \mathrm{~min}$ to yield a clear solution of a dark olive color. Then $7.2 \mathrm{~g} \mathrm{CH}_{3} \mathrm{COONa}$ and $2.0 \mathrm{~g}$ polyethylene glycol were added into the above solution with stirring in a $70{ }^{\circ} \mathrm{C}$ water-bath. After being stirred for 30 min, the mixture was transferred into a $100 \mathrm{~mL}$ Teflon-lined stainless steel autoclave, sealed and heated at $200{ }^{\circ} \mathrm{C}$ for $12 \mathrm{~h}$. After cooling to room temperature naturally, the formed products were collected by magnetic separation and then washed several times with ethanol and deoxygenated water. After being dried at $65{ }^{\circ} \mathrm{C}$ for $12 \mathrm{~h}$ in vacuum, the synthesized composites were crushed and stored under $\mathrm{N}_{2}$ atmosphere. And the preparation of non-doped $\mathrm{Fe}_{3} \mathrm{O}_{4}$ sample followed similar procedures except that no $\mathrm{CuCl}_{2} \cdot 2 \mathrm{H}_{2} \mathrm{O}$ was added.

\subsection{Characterization of Cu-doped $\mathrm{Fe}_{3} \mathrm{O}_{4}$ and non-doped $\mathrm{Fe}_{3} \mathrm{O}_{4}$ magnetic particle}

The specific surface area $\left(S_{\mathrm{BET}}\right)$ of samples were calculated by applying the multipoint Brunauer Emmett and Teller (BET) equation on the nitrogen adsorption data collected on an ASAP 2020 surface area analyzer (Micromeritics, USA). Prior to BET analysis, all samples were degassed under vacuum at $150{ }^{\circ} \mathrm{C}$ for 4 h. X-ray diffraction (XRD) patterns were recorded on an X'Pert PRO MPD X-ray diffractometer (PANalytical B.V., The Netherlands) equipped with $\mathrm{Cu} \mathrm{K} \alpha$ radiation. All diffraction patterns then analyzed using PANalytical X'Pert HighScore Plus 2.0 software packages and the peaks were matched using ICDD PDF-4+ 2004 database. The surface-sensitive analyses were performed with an X-ray photoelectron spectrometer (XPS) (Kratos, U.K) using a monochromatic Al-K $\alpha$ anode radiation source. The XPS results were fitted Gaussian-Lorentzian peak functions on a Shirley background using a nonlinear least squares curve fitting program (XPS Peak) and corrected using the $\mathrm{C}$ 1s level at $284.8 \mathrm{eV}$. The surface morphologies of nondoped $\mathrm{Fe}_{3} \mathrm{O}_{4}$ and $\mathrm{Cu}$-doped $\mathrm{Fe}_{3} \mathrm{O}_{4}$ were observed under the transmission electron microscope type H-7500 (Hitachi, Japan). The samples were injected into a flow cell of Zetasizer 2000 (Malvern, U.K.) and the particle electrophoretic mobility was measured to calculate the zeta potential. The Fourier transform infrared spectroscopy (FT-IR) spectra of original adsorbents and those with adsorbed $\mathrm{Sb}$ were collected at a range of 400-4000 $\mathrm{cm}^{-1}$ using a TENSOR 27 spectrometer (Bruker, Germany) by the $\operatorname{KBr}(1: 100$ ratio) pellet method. The room temperature $(300 \mathrm{~K})$ magnetic susceptibility and $M-H$ hysteresis loop of samples were investigated with Physical Property Measurement System (PPMS) equipped with a Vibrating Sample Magnetometer (VSM) (Quantum, USA).

\subsection{Batch adsorption experiments}

2.4.1 Adsorption kinetics. Batch adsorption kinetics experiments were conducted in 1 liter beaker with mechanical stirring (150 rev $\min ^{-1}$ ) at $25 \pm 1{ }^{\circ} \mathrm{C}$. For each experiment, $0.18 \mathrm{~g}$ non-doped $\mathrm{Fe}_{3} \mathrm{O}_{4} / \mathrm{Cu}$-doped $\mathrm{Fe}_{3} \mathrm{O}_{4}$ was added to $900 \mathrm{~mL}$ solutions with the initial concentration of $\mathrm{Sb}(\mathrm{III})$ and $\mathrm{Sb}(\mathrm{v})$ were 50 $\mathrm{mg} \mathrm{L}^{-1}$. The potassium nitrate $\left(\mathrm{KNO}_{3}\right)$ as the background electrolyte was added to get the ionic strength (IS) of $0.1 \mathrm{M}$. The $\mathrm{pH}$ was adjusted during adsorption using $0.1 \mathrm{M} \mathrm{NaOH}$ and 0.1 $\mathrm{M} \mathrm{HNO}_{3}$ to achieve pH variation in the range of $7.0 \pm 0.2$. Approximately $4 \mathrm{~mL}$ aliquots were taken at predetermined reaction time and the samples were immediately filtered through $0.45 \mu \mathrm{m}$ membrane and kept at $4 \pm 0.5{ }^{\circ} \mathrm{C}$ for further analysis. Finally, the adsorbents were collected by filtration, rinsed by deionized water, and freeze-dried for the further characterization.

To confirm the lower concentration antimony removal, a sorption study with $0.2 \mathrm{~g} \mathrm{~L}^{-1}$ adsorbent was conducted using initial $\mathrm{Sb}$ concentrations of $50 \mu \mathrm{g} \mathrm{\textrm {L } ^ { - 1 }}$. Other adsorption experimental procedures were the same as above.

2.4.2 Adsorption isotherms. Adsorption isotherms experiments were conducted in a $250 \mathrm{~mL}$ capped flask with continuous rotary shaking $\left(150 \mathrm{rev} \mathrm{min}^{-1}\right)$ by a thermostatic 
reciprocating shaker at $25 \pm 1{ }^{\circ} \mathrm{C}$. For each experiment, $0.02 \mathrm{~g}$ of adsorbent was added to $100 \mathrm{~mL}$ solutions with different initial antimony concentrations (in the range from 5 to $100 \mathrm{mg} \mathrm{L}^{-1}$ ) and shake for $12 \mathrm{~h}$. After adsorption, the suspensions were filtered through $0.45 \mu \mathrm{m}$ membrane filters for further analysis.

2.4.3 Effects of $\mathbf{p H}$ and ionic strength. While investigating the effects of $\mathrm{pH}$ on $\mathrm{Sb}$ sorption, the initial $\mathrm{pH}$ was adjusted to be in the range from 3.0 to 7.0 and 3.0 to 10.0 for the $\mathrm{Sb}$ (III) and $\mathrm{Sb}(\mathrm{v})$ adsorption systems, respectively. It was noted that $\mathrm{Sb}$ (III) tends to precipitate in the form of $\mathrm{Sb}_{2} \mathrm{O}_{3}$ at $\mathrm{pH}>7.0 .^{17}$ The solution $\mathrm{pH}$ was adjusted at different intervals during adsorption to avoid significant $\mathrm{pH}$ variation. While investigating the effects of IS on aqueous $\mathrm{Sb}$ adsorption, the $\mathrm{KNO}_{3}$ was added to obtain desired IS of $0.01 \mathrm{M}$ and $0.1 \mathrm{M}$. The suspensions were filtered through $0.45 \mu \mathrm{m}$ membrane after $12 \mathrm{~h}$ reaction, and the concentrations of $\mathrm{Sb}, \mathrm{Fe}$, and $\mathrm{Cu}$ in the supernatant were analyzed thereafter.

2.4.4 Effect of co-existing anions. The carbonate, sulfate, and phosphate widely exist in natural waters. To investigate their effects on antimony adsorption, batch experiments as noted above were preceded except that these anions $\left(\mathrm{CO}_{3}{ }^{2-}\right.$, $\mathrm{SO}_{4}{ }^{2-}$, and $\mathrm{PO}_{4}{ }^{3-}$ ) at 1 and $10 \mathrm{mM}$ were added prior to the addition of adsorbents. The adsorbent dose was $0.2 \mathrm{~g} \mathrm{~L}^{-1}$. The $\mathrm{pH}$ was maintained at $7.0 \pm 0.2$ and the temperature was controlled at $25 \pm 1{ }^{\circ} \mathrm{C}$.

2.4.5 Species transformation in adsorption process. The $\mathrm{Sb}$ (III) solutions at $50 \mathrm{mg} \mathrm{L}^{-1}$ were respectively purged with high purity $\mathrm{N}_{2}$ and $\mathrm{O}_{2}$ for $30 \mathrm{~min}$ and the dissolved oxygen (DO) of each sample was verified by a 550A meter (YSI, USA) before and after adsorption process. To avoid possible nitrate oxidation, $\mathrm{KNO}_{3}$ was not added and $\mathrm{pH}$ was adjusted to $7.0 \pm 0.2$ and 11.0 \pm 0.2 by using $0.1 \mathrm{M} \mathrm{NaOH}$ and $0.1 \mathrm{M} \mathrm{HCl}^{28}$ Dose of $0.2 \mathrm{~g} \mathrm{~L}^{-1}$ non-doped $\mathrm{Fe}_{3} \mathrm{O}_{4}$ or $\mathrm{Cu}$-doped $\mathrm{Fe}_{3} \mathrm{O}_{4}$ were added to the oxygenfree $\left(\mathrm{N}_{2}\right.$ purged, DO $\left.<0.1 \mathrm{mg} \mathrm{L^{-1 }}\right)$ and oxygen-enriched $\left(\mathrm{O}_{2}\right.$ purged, DO $>15.0 \mathrm{mg} \mathrm{L}^{-1}$ ) solution. Then all the flasks were carefully sealed to avoid air intrusion. Samples were shaken by a thermostatic reciprocating shaker $\left(150 \mathrm{rev} \min ^{-1}, 25 \pm 1{ }^{\circ} \mathrm{C}\right.$ ). The control experiments followed similar procedures except that no non-doped $\mathrm{Fe}_{3} \mathrm{O}_{4}$ or $\mathrm{Cu}$-doped $\mathrm{Fe}_{3} \mathrm{O}_{4}$ was added for determining aqueous antimony species transformation. After $12 \mathrm{~h}$ adsorption, about $5 \mathrm{~mL}$ suspension was collected and filtered through $0.45 \mu \mathrm{m}$ membrane filters to analyze the aqueous $\mathrm{Sb}(\mathrm{III}) /(\mathrm{v})$. The analysis of aqueous copper species transformation followed similar procedures except using the $\mathrm{Sb}(\mathrm{III}), \mathrm{Sb}(\mathrm{v})$ and non-adsorbate solution as comparisons.

\subsection{Analytical methods}

The concentrations of total $\mathrm{Sb}, \mathrm{Cu}$, and $\mathrm{Fe}$ in aqueous samples acidified with $\mathrm{HNO}_{3}(1 \% \mathrm{v} / \mathrm{v})$ were determined by the Agilent 710 Inductively Coupled Plasma Optical Emission Spectrometry (ICP-OES) (Agilent Co., USA). The AF-630A hydride generation atomic fluorescence spectrometer (HG-AFS) (Beifen-Ruili, China) was employed to analyze the valence state of aqueous $\mathrm{Sb}^{29}$ The concentrations of aqueous $\mathrm{Cu}^{\mathrm{I}}$ were spectrophotometrically determined using a modified bathocuproine method. ${ }^{30,31}$ The reactions between $\mathrm{Cu}(\mathrm{I})$ and bathocuproine contributed to the formation of $\mathrm{Cu}(\mathrm{I})$-bathocuproine complex. This complex may be quantitatively measured at $484 \mathrm{~nm}$ with a T6 spectrophotometer (Persee, China) against a blank solution in a $10 \mathrm{~cm}$ cell. The concentration of $\mathrm{Cu}^{\mathrm{II}}$ was calculated by subtracting $\mathrm{Cu}^{\mathrm{I}}$ from the total dissolved copper.

\section{Results and discussions}

\subsection{Characterization of $\mathrm{Fe}_{3} \mathrm{O}_{4}$ and $\mathrm{Cu}$-doped $\mathrm{Fe}_{3} \mathrm{O}_{4}$ microspheres}

The dominant reactions involved in the preparation of $\mathrm{Cu}$ doped $\mathrm{Fe}_{3} \mathrm{O}_{4}$ and non-doped $\mathrm{Fe}_{3} \mathrm{O}_{4}$ are as follows:

$$
\mathrm{Fe}^{3+}+3 \mathrm{CH}_{3} \mathrm{COO}^{-}+3 \mathrm{H}_{2} \mathrm{O} \rightarrow \mathrm{Fe}(\mathrm{OH})_{3}+3 \mathrm{CH}_{3} \mathrm{COOH}
$$

Here, ethylene glycol acts as the reductant and surfactant for the synthesis of monodispersed particles. ${ }^{32}$

$$
\mathrm{Fe}(\mathrm{OH})_{3}+{ }^{\mathrm{HO}} \mathrm{OH}_{\mathrm{OH}} \stackrel{200^{\circ} \mathrm{C}}{\longrightarrow} \mathrm{Fe}(\mathrm{OH})_{2}+\mathrm{HO} \mathrm{CO}_{\mathrm{O}}+\mathrm{H}_{2} \mathrm{O}
$$

Finally, these iron(III) and copper(II)/iron(II) hydroxides react to form magnetite structures:

$$
2 \mathrm{Fe}(\mathrm{OH})_{3}+\mathrm{Cu}(\mathrm{OH})_{2} / \mathrm{Fe}(\mathrm{OH})_{2} \rightarrow \mathrm{CuFe}_{2} \mathrm{O}_{4} / \mathrm{Fe}_{3} \mathrm{O}_{4} \downarrow+4 \mathrm{H}_{2} \mathrm{O}
$$

Chemical composition analysis revealed that the molar ratio of $\mathrm{Cu}$ to $\mathrm{Fe}$ on the $\mathrm{Cu}$-doped $\mathrm{Fe}_{3} \mathrm{O}_{4}$ surface was $1: 2.32$ (Table $\mathrm{S} 1 \dagger$ ), and this was close to that of the precursors, i.e., $1: 2$. The chemical formula of non-doped $\mathrm{Fe}_{3} \mathrm{O}_{4}$ and $\mathrm{Cu}$-doped $\mathrm{Fe}_{3} \mathrm{O}_{4}$ may be expressed as $\mathrm{Fe}_{3.15} \mathrm{O}_{4}$ and $\mathrm{Cu}_{0.72} \mathrm{Fe}_{1.66} \mathrm{O}_{4}$. The XRD patterns of the non-doped $\mathrm{Fe}_{3} \mathrm{O}_{4}$ and $\mathrm{Cu}$-doped $\mathrm{Fe}_{3} \mathrm{O}_{4}$ adsorbents are illustrated in Fig. 1(a). As indicated from the XRD patterns, all the peaks in both non-doped and $\mathrm{Cu}$-doped $\mathrm{Fe}_{3} \mathrm{O}_{4}$ can be assigned to the inverse cubic spinel structure, and the crystal structure of the $\mathrm{Cu}$-doped is inferred to be similar to that of $\mathrm{Fe}_{3} \mathrm{O}_{4}$. The peaks of non-doped $\mathrm{Fe}_{3} \mathrm{O}_{4}$ are observed at $2 \theta=30.05^{\circ}, 35.30^{\circ}, 42.93^{\circ}$, $56.93^{\circ}$, and $62.49^{\circ}$, and these peaks respectively represent the Bragg reflections from the (220), (311), (400), (511), and (440) planes (as identified by ICDD card 01-086-1356). It is noted that a weak peak of residual $\mathrm{FeCl}_{3}\left(2 \theta\right.$ at $\left.33.42^{\circ}\right)$ can also be observed (ICDD card 00-001-1059). The XRD patterns of the Cu-doped $\mathrm{Fe}_{3} \mathrm{O}_{4}$ were indexed as $\mathrm{CuFe}_{2} \mathrm{O}_{4}$ (ICDD card 01-077-0427), and the newly-appeared peak at $43.36^{\circ}$ was attributed to $\mathrm{Cu}^{\circ}$ (ICDD card 03-065-9026) and those at $36.49^{\circ}$ and $42.42^{\circ}$ could match the $\mathrm{Cu}_{2}^{\mathrm{I}} \mathrm{O}$ card (ICDD card 01-077-0199). This indicated the partial reduction of $\mathrm{Cu}^{\mathrm{II}}$ to $\mathrm{Cu}^{0} / \mathrm{Cu}^{\mathrm{I}}$ during the synthesis of $\mathrm{Cu}$ doped $\mathrm{Fe}_{3} \mathrm{O}_{4}$. Additionally, the peaks of $\mathrm{Cu} 2 \mathrm{p}$ in the XPS data indicated that there had two or three copped species $\left(\mathrm{Cu}^{0} / \mathrm{Cu}^{\mathrm{I}}\right.$ and $\mathrm{Cu}^{\mathrm{II}}$ ) in the $\mathrm{Cu}$-doped $\mathrm{Fe}_{3} \mathrm{O}_{4}$ sample (Fig. S1 $\dagger$ ). Moreover, several XRD peaks were observed to gradually shift to higher diffraction angles after Cu-doping. This may be attributed to the slight change in the lattice constant after the substitution of $\mathrm{Fe}^{2+} / \mathrm{Fe}^{3+}$ ions by copper ions with different ionic radius. ${ }^{26,33}$

The doping of $\mathrm{Cu}$ into $\mathrm{Fe}_{3} \mathrm{O}_{4}$ also showed effects on the binding energy (BE) of elemental Fe [Fig. 1(b)]. The levels of Fe 

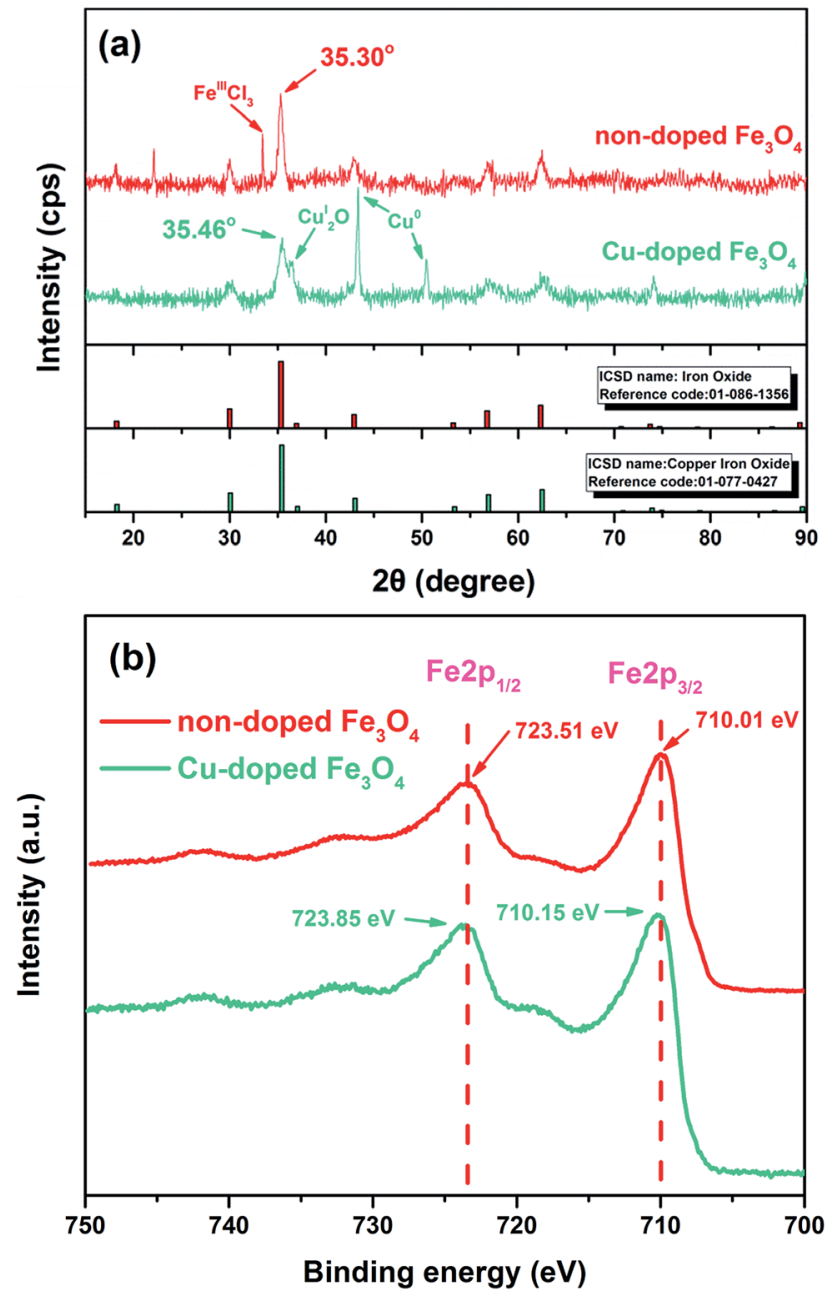

Fig. 1 (a) XRD patterns and (b) XPS results of Fe $2 p$ core level photoelectron spectra of non-doped $\mathrm{Fe}_{3} \mathrm{O}_{4}$ and $\mathrm{Cu}$-doped $\mathrm{Fe}_{3} \mathrm{O}_{4}$.

$2 \mathrm{p}_{3 / 2}$ and Fe $2 \mathrm{p}_{1 / 2}$ were determined to be 710.01 and $723.51 \mathrm{eV}$ for $\mathrm{Fe}_{3} \mathrm{O}_{4}$, and these results are in accordance with previous study. ${ }^{34}$ After Cu doping, the peaks of $\mathrm{Fe} 2 \mathrm{p}_{3 / 2}$ and Fe $2 \mathrm{p}_{1 / 2}$ shift to higher binding energy of 710.15 and $723.85 \mathrm{eV}$. The higher binding energy was relative to higher positive oxidation state, owing to the extra coulombic interaction between the photoemitted electron and the ion core. It is reported that the divalent iron $\left(\mathrm{Fe}^{\mathrm{II}}\right.$ ) within $\mathrm{Fe}_{3} \mathrm{O}_{4}$ may be partly or fully replaced by other divalent ions such as $\mathrm{Cu}^{\mathrm{II}} \cdot{ }^{33,35}$ The shift of $\mathrm{Fe} 2 \mathrm{p}$ XPS peaks revealed the substitution of the $\mathrm{Fe}^{\mathrm{II}}$ sites (octahedral or tetrahedral) by $\mathrm{Cu}^{\mathrm{II}}$, and the ratio of elemental $\mathrm{Fe}$ with higher oxidation state $\left(\mathrm{Fe}^{\mathrm{III}}\right)$ was increased thereafter.

The BET surface areas $\left(S_{\mathrm{BET}}\right)$ of samples calculated from nitrogen adsorption and desorption isotherm plot [Fig. 2(a)]. The Cu-doped $\mathrm{Fe}_{3} \mathrm{O}_{4}$ sample showed higher $S_{\mathrm{BET}}$ of $67.20 \mathrm{~m}^{2} \mathrm{~g}^{-1}$ than non-doped $\mathrm{Fe}_{3} \mathrm{O}_{4}\left(S_{\mathrm{BET}}=9.66 \mathrm{~m}^{2} \mathrm{~g}^{-1}\right)$. According to the IUPAC classification, all the samples exhibit type-IV isotherms with a very narrow hysteresis loop in the relative pressure $\left(P / P_{0}\right)$ range of $0.4-1.0$, which exhibits a typical less-pore structure. ${ }^{36}$ The increased surface area also is seen in the representative TEM images [Fig. 2(b)]. The standard deviation of particle size
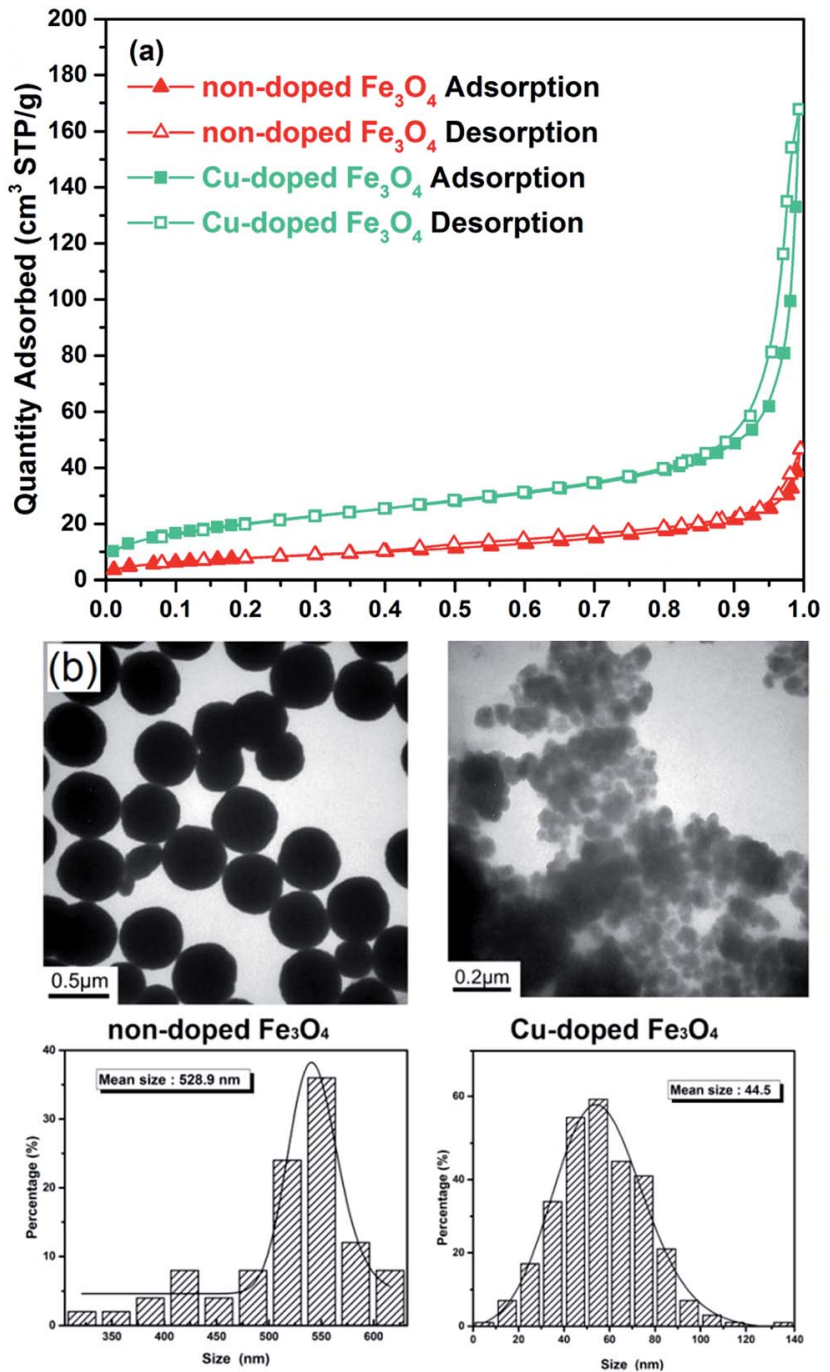

Fig. 2 (a) $\mathrm{N}_{2}$ adsorption (solid symbols) and desorption (open symbols) isotherm of $\mathrm{Fe}_{3} \mathrm{O}_{4}$ and $\mathrm{Cu}$-doped $\mathrm{Fe}_{3} \mathrm{O}_{4}$ at $77 \mathrm{~K}$ (b) TEM images and size distribution of non-doped $\mathrm{Fe}_{3} \mathrm{O}_{4}$ and $\mathrm{Cu}$-doped $\mathrm{Fe}_{3} \mathrm{O}_{4}$ with Gaussian fitting.

was found to be $528.9 \mathrm{~nm}$ for $\mathrm{Fe}_{3} \mathrm{O}_{4}$ and $44.5 \mathrm{~nm}$ for $\mathrm{Cu}$-doped $\mathrm{Fe}_{3} \mathrm{O}_{4}$. Additionally, the non-doped $\mathrm{Fe}_{3} \mathrm{O}_{4}$ were spherical with narrow size distributions, whereas the $\mathrm{Cu}$-doped $\mathrm{Fe}_{3} \mathrm{O}_{4}$ showed much smaller size with roughen edges. In a typical solvothermal process, the diameters of the ferrite microspheres are influenced by reaction time, the species types, and concentrations of raw materials, ${ }^{27}$ which is suitable for adsorbent optimization. The co-precipitation method may also synthesize the $\mathrm{Fe}_{3} \mathrm{O}_{4}$ and $\mathrm{Cu}$-doped $\mathrm{Fe}_{3} \mathrm{O}_{4}$ and their particle diameter was reported to be 14.49 and $11.78 \mathrm{~nm}$, respectively. ${ }^{25}$ The obtained materials in this study exhibited larger particle size and were easier to be removed by magnetic separation [eqn (S1) † ]. ${ }^{37}$ The doping of $\mathrm{Cu}$ into $\mathrm{Fe}_{3} \mathrm{O}_{4}$ decreased the particle size, increased surface area, and may provide more active sites available for adsorption as compared to $\mathrm{Fe}_{3} \mathrm{O}_{4}$.

The magnetic particles with higher saturation magnetization are more susceptible to magnetic field, and can be easier separated by magnetic separation. The magnetic properties of 


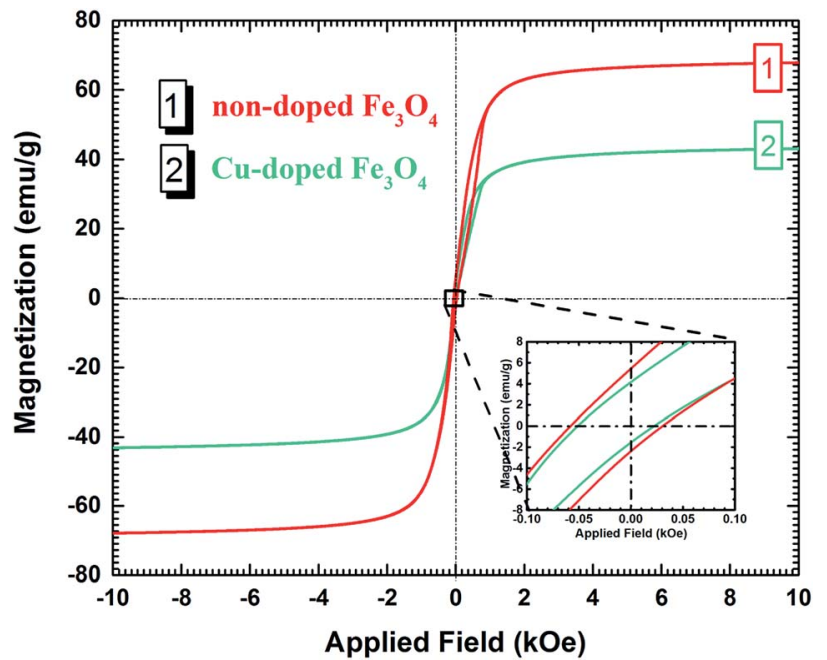

Fig. 3 Magnetization curve of (1) non-doped $\mathrm{Fe}_{3} \mathrm{O}_{4}$ and (2) $\mathrm{Cu}$-doped $\mathrm{Fe}_{3} \mathrm{O}_{4}$.

the non-doped $\mathrm{Fe}_{3} \mathrm{O}_{4}$ and $\mathrm{Cu}$-doped $\mathrm{Fe}_{3} \mathrm{O}_{4}$ particles were compared by the magnetization curves measured by VSM at 300 $\mathrm{K}$ (Fig. 3). The magnetic saturation value $\left(M_{\mathrm{S}}\right)$ of the $\mathrm{Cu}$-doped $\mathrm{Fe}_{3} \mathrm{O}_{4}$ was determined to be $43.1 \mathrm{emu} \mathrm{g}^{-1}$, whereas that of the $\mathrm{Fe}_{3} \mathrm{O}_{4}$ was observed to be $67.1 \mathrm{emu} \mathrm{g}^{-1}$. The decreased $M_{\mathrm{s}}$ might be attributed to $\mathrm{Cu}^{2+}$ substituting the iron cations $\left(\mathrm{Fe}^{2+}\right.$ or $\left.\mathrm{Fe}^{3+}\right)$ from the lattice, and this effect resulted in disordered structure and decreased magnetic properties accordingly. ${ }^{38}$ Generally, the obtained $\mathrm{Cu}$-doped $\mathrm{Fe}_{3} \mathrm{O}_{4}$ showed relatively high $M_{\mathrm{S}}$ as compared with other magnetic adsorbents [e.g. $\mathrm{MnFe}_{2} \mathrm{O}_{4}(35.2$ emu $\left.\mathrm{g}^{-1}\right),{ }^{39}$ Ascorbic acid coated $\mathrm{Fe}_{3} \mathrm{O}_{4}$ (40.0 emu $\left.\mathrm{g}^{-1}\right),{ }^{40}$ magnesium ferrite $\left.\left(32.9 \mathrm{emu} \mathrm{g}^{-1}\right)^{41}\right]$, and the $\mathrm{Cu}$-doped $\mathrm{Fe}_{3} \mathrm{O}_{4}$ is viewed as a promising magnetic adsorbent which could be separated by a magnetic field easily.

\subsection{Adsorptive behaviors of $\mathrm{Fe}_{3} \mathrm{O}_{4}$ and $\mathrm{Cu}$-doped $\mathrm{Fe}_{3} \mathrm{O}_{4}$ towards $\mathrm{Sb}(\mathrm{III})$ and $\mathrm{Sb}(\mathrm{v})$}

3.2.1 Adsorption kinetics. The effect of contact time on the $\mathrm{Sb}$ adsorption was examined to determine the time required for reaching adsorption equilibrium. Fig. 4 illustrates the adsorption density $\left(q_{t}\right)$ of $\mathrm{Sb}(\mathrm{III})$ and $\mathrm{Sb}(\mathrm{v})$ onto these two microspheres with prolonged contact time $(t)$. Three adsorption kinetic models, ${ }^{42,43}$ Pseudo-first-order eqn (4), Pseudo-second-order eqn (5), and Elovich model eqn (6), were used to fit the experimental data and the obtained kinetic parameters are summarized in Table 1.

$$
\begin{array}{r}
q_{t}=q_{\mathrm{e}}\left(1-e^{-k_{1} t}\right) \\
q_{t}=\frac{q_{\mathrm{e}}{ }^{2} k_{2} t}{1+q_{\mathrm{e}} k_{2} t} \\
q_{t}=k_{3} \ln (t)+C
\end{array}
$$

where $q_{\mathrm{e}}$ and $q_{t}\left(\mathrm{mg} \mathrm{g}^{-1}\right)$ are the amounts of solute sorbed on the surface of the sorbent at equilibrium and at time $t$ (min), respectively. The $k_{1}, k_{2}$, and $k_{3}$ are the rate constants of the Pseudo-first-order, Pseudo-second-order, and Elovich equations, respectively.

It was observed that $\mathrm{Cu}$-doped $\mathrm{Fe}_{3} \mathrm{O}_{4}$ had higher adsorption density and velocity towards $\mathrm{Sb}$ (III) and $\mathrm{Sb}(\mathrm{v})$ than $\mathrm{Fe}_{3} \mathrm{O}_{4}$, and the adsorption process could be divided into three stages. In the initial rapid adsorption stage $(0-1 \mathrm{~h})$, Cu-doped $\mathrm{Fe}_{3} \mathrm{O}_{4}$ contributed to the $q_{t}$ of $77.9 \%$ and $94.2 \%$ to the equilibrium sorption capacity $\left(q_{\mathrm{e}}\right)$ of $\mathrm{Sb}(\mathrm{v})$ and $\mathrm{Sb}(\mathrm{III})$, respectively. In the second stage (1-6 h), the intra-particle diffusion dominated in the adsorption of $\mathrm{Sb}$, and the adsorption rate slowed down greatly. The $6 \mathrm{~h}$ contact time could achieve over $93 \%$ of the $q_{\mathrm{e}}$ for all samples. In the third stage (6-12 h), the $q_{t}$ of both $\mathrm{Sb}(\mathrm{III})$ and $\mathrm{Sb}(\mathrm{v})$ showed little variation, and the contact time of $12 \mathrm{~h}$ was sufficient to approach the equilibrium.

As indicated from $R^{2}$ values (Table 1), Pseudo-first-order equation model was best fitted to describe the adsorption of $\mathrm{Sb}$ (III) onto $\mathrm{Fe}_{3} \mathrm{O}_{4}$ and that of $\mathrm{Sb}(\mathrm{v})$ onto $\mathrm{Cu}$-doped $\mathrm{Fe}_{3} \mathrm{O}_{4}$. Comparatively, Elovich equation fitted best for the adsorption of $\mathrm{Sb}(\mathrm{v})$ onto $\mathrm{Fe}_{3} \mathrm{O}_{4}$ and that of $\mathrm{Sb}$ (III) onto $\mathrm{Cu}$-doped $\mathrm{Fe}_{3} \mathrm{O}_{4}$. Elovich model is relative to the adsorption on highlyheterogeneous surfaces with the dominant mechanisms of surface chemisorption. ${ }^{\mathbf{4 4}}$

In natural condition, antimony concentration usually presents less than $50 \mu \mathrm{g} \mathrm{L}^{-1}$ in freshwater systems. ${ }^{45}$ It is necessary to treat antimony-contaminated water and control the antimony concentration to permissible limits, which are $10 \mu \mathrm{g} \mathrm{L}^{-1}$ and $6 \mu \mathrm{g}$ $\mathrm{L}^{-1}$ in the World Health Organization (WHO) and US EPA guidelines, ${ }^{\mathbf{4 6 , 4 7}}$ respectively. As shown in Fig. S2(a), $\dagger$ the initial $\mathrm{Sb}$ (III) concentration was about $50.0 \mu \mathrm{g} \mathrm{L}^{-1}$ and the equilibrium adsorption capacity, whatever non-doped or $\mathrm{Cu}$-doped $\mathrm{Fe}_{3} \mathrm{O}_{4}$, was achieved within $4 \mathrm{~h}$. Furthermore, the removal rate was over $90 \%$, and the residual antimony concentration was lower than the guidelines of WHO and US EPA. However, we found that $\mathrm{Sb}(\mathrm{v})$ was more difficult to be removed using the same procedure [Fig. S2(b) $\dagger$ ]. The non-doped $\mathrm{Fe}_{3} \mathrm{O}_{4}$ removed the aqueous $\mathrm{Sb}(\mathrm{v})$ from $50.0 \mu \mathrm{g} \mathrm{L}^{-1}$ to $12.87 \mu \mathrm{g} \mathrm{L}^{-1}$, which exceeded the WHO and EPA drinking water guideline. Similar to the high $\mathrm{Sb}$ concentration study's findings, the Cu-doped $\mathrm{Fe}_{3} \mathrm{O}_{4}$ showed more $\mathrm{Sb}(\mathrm{v})$ adsorption capacity than non-doped $\mathrm{Fe}_{3} \mathrm{O}_{4}$. The residual $\mathrm{Sb}$ concentration was detected only $4.47 \mu \mathrm{g} \mathrm{L}^{-1}$ after treated with $\mathrm{Cu}$ doped $\mathrm{Fe}_{3} \mathrm{O}_{4} . \mathrm{Sb}(\mathrm{v})$ is the principal form of antimony in the aqueous environments, ${ }^{48}$ as compared to $\mathrm{Sb}$ (III). Therefore, high adsorption capacity of $\mathrm{Sb}(\mathrm{v})$ is more meaningful to practical application.

Additionally, it was observed that $\mathrm{Sb}(\mathrm{III})$ easily adsorbed onto these two adsorbents than $\mathrm{Sb}(\mathrm{v})$ and the obtained $q_{\mathrm{e}, \mathrm{Sb}(\mathrm{III})}$ values were twice or more to those of $q_{\mathrm{e}, \mathrm{Sb}(\mathrm{v})}$. This trend is contrary to that of As(III) which is more difficult to be removed than $\mathrm{As}(\mathrm{v})$ by adsorption process. ${ }^{26}$ The reduction of $\mathrm{Sb}(\mathrm{v})$ to $\mathrm{Sb}$ (III) is inferred to improve $\mathrm{Sb}$ removal; unfortunately, it was rather difficult to achieve on the basis of thermodynamic considerations and operational requirements. The development of novel adsorbents with high capability towards $\mathrm{Sb}(\mathrm{v})$ is of crucial importance, and the Cu-doping greatly improves the adsorption capability of $\mathrm{Fe}_{3} \mathrm{O}_{4}$ towards $\mathrm{Sb}(\mathrm{v})$ which is practically valuable. 

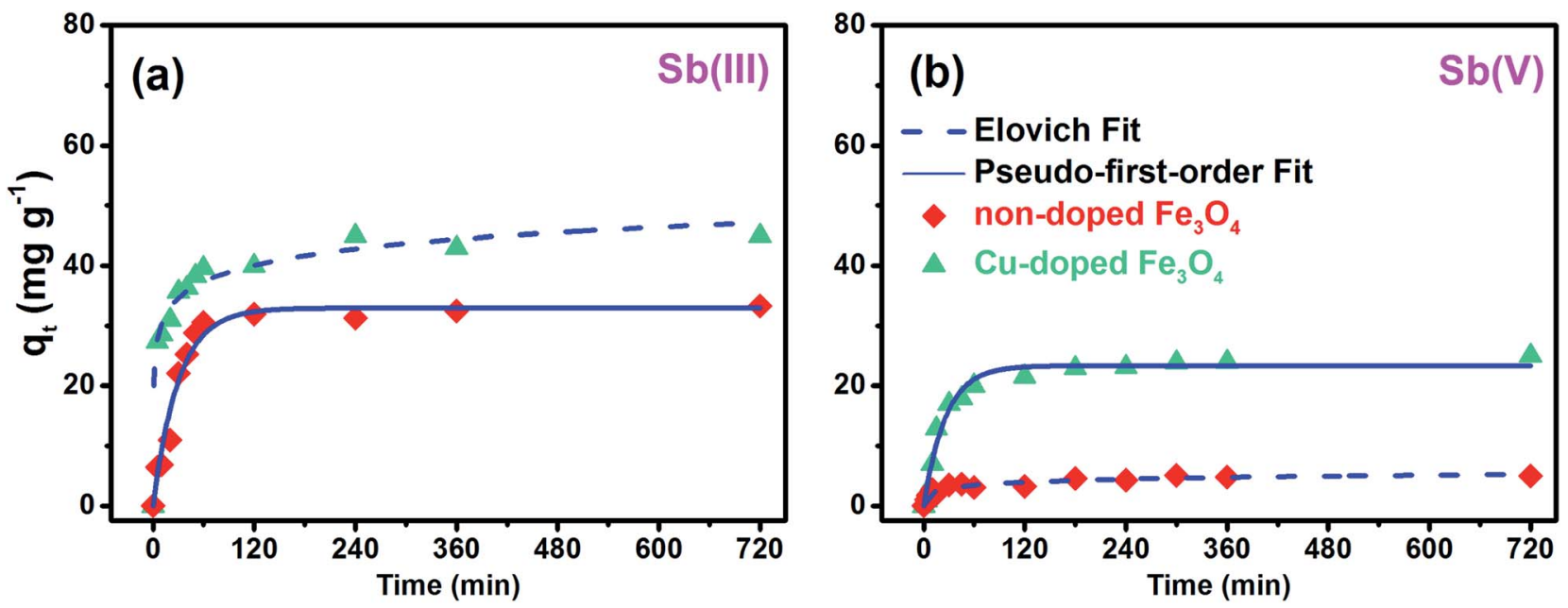

Fig. 4 Adsorption kinetics of (a) Sb(III) and (b) $\mathrm{Sb}(\mathrm{v})$ on $\mathrm{Fe}_{3} \mathrm{O}_{4}$ and $\mathrm{Cu}$-doped $\mathrm{Fe}_{3} \mathrm{O}_{4}\left([\mathrm{Sb}(\mathrm{II})]_{0}=[\mathrm{Sb}(\mathrm{v})]_{0}=50 \mathrm{mg} \mathrm{L}^{-1}\right.$, adsorbents doses $=0.2 \mathrm{~g} \mathrm{~L}-1$, $\mathrm{pH}=7.0$ ).

3.2.2 Adsorption isotherms. Fig. 5 illustrates the adsorption isotherms of $\mathrm{Sb}(\mathrm{III})$ and $\mathrm{Sb}(\mathrm{v})$ onto these two adsorbents, and the fitted constants by Langmuir eqn (7), Freundlich eqn (8), Langmuir 2-surface eqn (9) and Sips isotherm eqn (10) that are presented in Table 2.

$$
\begin{gathered}
q_{\mathrm{e}}=\frac{K_{\mathrm{L}} q_{\mathrm{m}} C_{\mathrm{e}}}{1+K_{\mathrm{L}} C_{\mathrm{e}}} \\
q_{\mathrm{e}}=K_{\mathrm{F}}\left(C_{\mathrm{e}}\right)^{\frac{1}{n}} \\
q_{\mathrm{e}}=\frac{q_{\mathrm{m} 1} b_{1} C_{\mathrm{e}}}{1+b_{1} C_{\mathrm{e}}}+\frac{q_{\mathrm{m} 2} b_{2} C_{\mathrm{e}}}{1+b_{2} C_{\mathrm{e}}} \\
q_{\mathrm{e}}=\frac{q_{\mathrm{m}}\left(b_{3} C_{\mathrm{e}}\right)^{\beta}}{1+\left(b_{3} C_{\mathrm{e}}\right)^{\beta}}
\end{gathered}
$$

where, $q_{\mathrm{e}}$ is the amount of antimony adsorbed on the solid phase $\left(\mathrm{mg} \mathrm{g}^{-1}\right), C_{\mathrm{e}}$ is the equilibrium antimony concentration in the solution $\left(\mathrm{mg} \mathrm{L}^{-1}\right), q_{\mathrm{m}}$ is the monolayer adsorption capacity of the sorbent $\left(\mathrm{mg} \mathrm{g}^{-1}\right)$, and $K_{\mathrm{L}}$ and $b_{3}$ are the Langmuir adsorption constant $\left(\mathrm{L} \mathrm{mg}^{-1}\right)$ related with the free energy of adsorption. $K_{\mathrm{F}}$ is a constant relating the adsorption capacity and $1 / n$ is an empirical parameter relating the adsorption intensity. In eqn (9), $q_{\mathrm{m} 1}$ and $q_{\mathrm{m} 2}$ represent as monolayer adsorption capacity of two different active sites respectively and $b_{1}, b_{2}$ as the adsorption/ desorption equilibrium constant related to the bonding energy.
Langmuir and Langmuir 2-surface isotherms assume monolayer adsorption onto surfaces with finite adsorption sites and no transmigration of adsorbate in the plane of surfaces. Comparatively, Freundlich isotherm assumes heterogeneous surface energies, in which the energy term in Langmuir equation varies as the function of surface coverage. ${ }^{49}$ The Sips isotherm is the combination of Langmuir and Freundlich isotherms and assumes that the distribution of binding affinities of the adsorption sites with the adsorbate can be described by a Gaussian-like distribution expression. ${ }^{50}$ In eqn (10), $q_{\mathrm{m}}(\mathrm{mg}$ $\left.\mathrm{g}^{-1}\right)$ and $b_{3}\left(\mathrm{~L} \mathrm{mg}^{-1}\right)$ have the same meaning as $q_{\mathrm{m}}$ and $K_{\mathrm{L}}$ in Langmuir model, whereas the exponent $\beta$ introduced from Freundlich model indicates the heterogeneity of the adsorption sites. The applicability of these isotherms was compared by the $R^{2}$ coefficients.

Results in Fig. 5 and Table 2 indicated that these four models could well describe the adsorption of $\mathrm{Sb}$ (III) and $\mathrm{Sb}(\mathrm{v})$ onto these two adsorbents with $R^{2}$ ranging from 0.799 to 0.987 . The obtained $q_{\mathrm{m}}$ values from the Langmuir isotherm of $\mathrm{Sb}$ (III) and $\mathrm{Sb}(\mathrm{v}$ ) on $\mathrm{Cu}$-doped $\mathrm{Fe}_{3} \mathrm{O}_{4}$ was 1.41 and 4.87 times to those on $\mathrm{Fe}_{3} \mathrm{O}_{4}$ surfaces. Comparatively, Cu-doped $\mathrm{Fe}_{3} \mathrm{O}_{4}$ could provide more active sites available to capture antimony than $\mathrm{Fe}_{3} \mathrm{O}_{4}$. Table 2 indicated that the Sips isotherm was best to describe the adsorption of $\mathrm{Sb}$ (III) and $\mathrm{Sb}(\mathrm{v})$ onto $\mathrm{Fe}_{3} \mathrm{O}_{4}$ and that of $\mathrm{Sb}$ (III) onto

\begin{tabular}{|c|c|c|c|c|c|c|c|c|c|c|}
\hline \multirow{2}{*}{\multicolumn{2}{|c|}{ Condition }} & \multicolumn{3}{|c|}{ Pseudo-first-order equation } & \multicolumn{3}{|c|}{ Pseudo-second-order equation } & \multicolumn{3}{|c|}{ Elovich equation } \\
\hline & & $q_{\mathrm{e}}\left(\mathrm{mg} \mathrm{g}^{-1}\right)$ & $K_{1}$ & $R^{2}$ & $q_{\mathrm{e}}\left(\mathrm{mg} \mathrm{g}^{-1}\right)$ & $K_{2}$ & $R^{2}$ & $C$ & $K_{3}$ & $R^{2}$ \\
\hline \multirow[t]{2}{*}{$\mathrm{Sb}(\mathrm{III})$} & $\mathrm{Fe}_{3} \mathrm{O}_{4}$ & 32.84 & 0.03 & 0.964 & 37.13 & 0.001 & 0.924 & -4.72 & 7.17 & 0.862 \\
\hline & $\mathrm{Cu}$-doped $\mathrm{Fe}_{3} \mathrm{O}_{4}$ & 38.89 & 0.17 & 0.890 & 41.95 & 0.006 & 0.959 & 20.10 & 4.29 & 0.987 \\
\hline \multirow[t]{2}{*}{$\mathrm{Sb}(\mathrm{v})$} & $\mathrm{Fe}_{3} \mathrm{O}_{4}$ & 4.14 & 0.07 & 0.818 & 4.56 & 0.018 & 0.883 & 0.45 & 0.74 & 0.920 \\
\hline & $\mathrm{Cu}$-doped $\mathrm{Fe}_{3} \mathrm{O}_{4}$ & 22.99 & 0.04 & 0.980 & 25.65 & 0.002 & 0.976 & -2.92 & 4.97 & 0.950 \\
\hline
\end{tabular}
$\mathrm{Cu}$-doped $\mathrm{Fe}_{3} \mathrm{O}_{4}$. The adsorption of $\mathrm{Sb}(\mathrm{v})$ onto $\mathrm{Cu}$-doped $\mathrm{Fe}_{3} \mathrm{O}_{4}$ could be best described by the Langmuir 2-surface model which

Table 1 Adsorption kinetics constants for the adsorption of $\mathrm{Sb}(\mathrm{II})$ and $\mathrm{Sb}(\mathrm{V})$ onto $\mathrm{Fe}_{3} \mathrm{O}_{4}$ and $\mathrm{Cu}$-doped $\mathrm{Fe}_{3} \mathrm{O}_{4}$ 

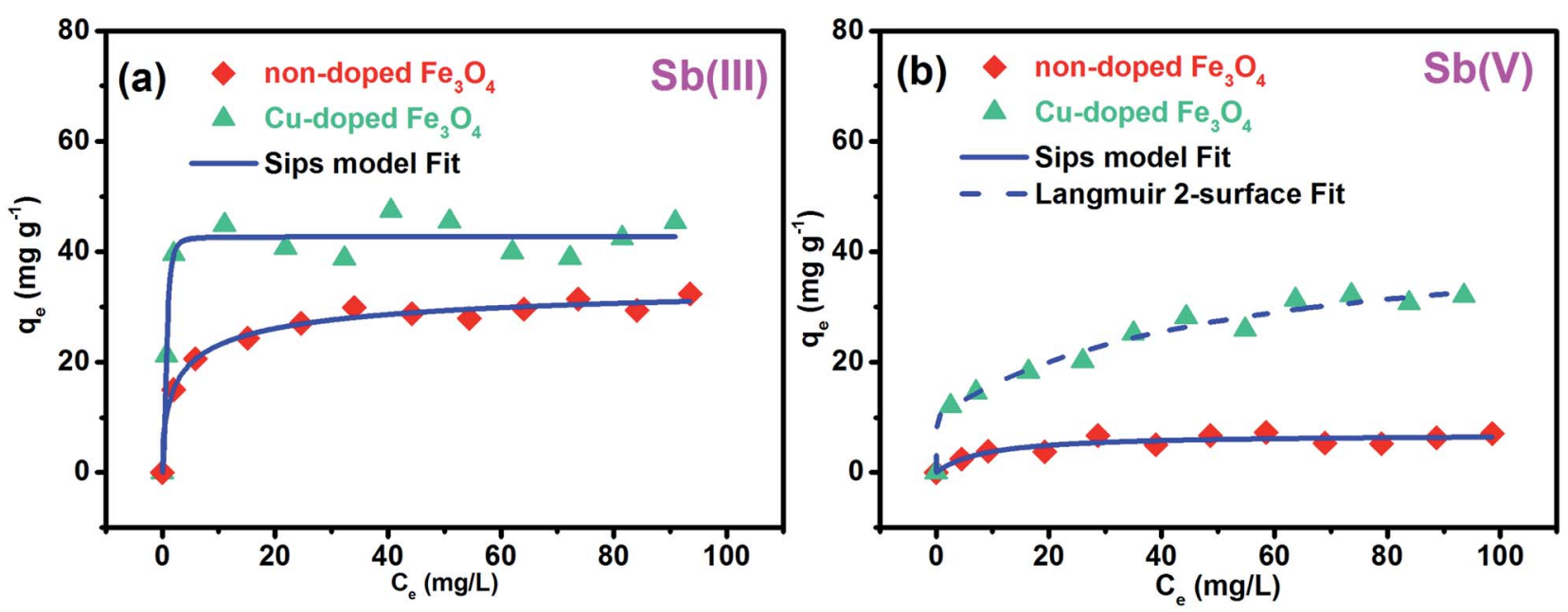

Fig. 5 Adsorption isotherms of (a) $\mathrm{Sb}(I I)$ and (b) $\mathrm{Sb}(\mathrm{v})$ on $\mathrm{Fe}_{3} \mathrm{O}_{4}$ and $\mathrm{Cu}$-doped $\mathrm{Fe}_{3} \mathrm{O}_{4}\left([\mathrm{Sb}(I I)]_{0}=[\mathrm{Sb}(\mathrm{v})]_{0}=5,10,20,30,40,50,60,70,80,90,100\right.$ $\mathrm{mg} \mathrm{L}-1$, adsorbents doses $=0.2 \mathrm{~g} \mathrm{~L}^{-1}, \mathrm{pH}=7.0$ ).

Table 2 The fitted parameters for the adsorption of $\mathrm{Sb}(\mathrm{II})$ and $\mathrm{Sb}(\mathrm{v})$ on $\mathrm{Fe}_{3} \mathrm{O}_{4}$ and $\mathrm{Cu}$-doped $\mathrm{Fe}_{3} \mathrm{O}_{4}$

\begin{tabular}{|c|c|c|c|c|c|c|c|c|c|c|c|c|}
\hline & & \multicolumn{3}{|l|}{ Langmuir } & \multicolumn{3}{|c|}{ Freundlich } & \multicolumn{2}{|l|}{ Sips } & \multicolumn{3}{|c|}{ Langmuir 2-surface } \\
\hline \multicolumn{2}{|c|}{ Condition } & $q_{\max }\left(\mathrm{mg} \mathrm{g}^{-1}\right)$ & $K_{\mathrm{L}}$ & $R^{2}$ & $n$ & $K_{\mathrm{F}}$ & $R^{2}$ & $q$ & $R^{2}$ & $q_{\mathrm{m} 1}$ & $q_{\mathrm{m} 2}$ & $R^{2}$ \\
\hline \multirow[t]{2}{*}{$\mathrm{Sb}(\mathrm{III})$} & $\mathrm{Fe}_{3} \mathrm{O}_{4}$ & 30.92 & 0.378 & 0.975 & 6.061 & 15.19 & 0.975 & 35.8 & 0.987 & 19.6 & 13.7 & 0.987 \\
\hline & $\mathrm{Cu}$-doped $\mathrm{Fe}_{3} \mathrm{O}_{4}$ & 43.55 & 1.78 & 0.926 & 12.69 & 31.40 & 0.853 & 42.6 & 0.958 & 23.2 & 20.2 & 0.932 \\
\hline \multirow[t]{2}{*}{$\mathrm{Sb}(\mathrm{v})$} & $\mathrm{Fe}_{3} \mathrm{O}_{4}$ & 7.068 & 0.116 & 0.832 & 4.01 & 2.183 & 0.799 & 6.94 & 0.847 & 3.53 & 3.53 & 0.847 \\
\hline & $\mathrm{Cu}$-doped $\mathrm{Fe}_{3} \mathrm{O}_{4}$ & 34.46 & 0.089 & 0.925 & 3.266 & 8.206 & 0.976 & 36.75 & 0.95 & 34.43 & 10.05 & 0.982 \\
\hline
\end{tabular}

is often used to describe the heterogeneous surfaces with different bonding energies. The surface sites on $\mathrm{Cu}$-doped $\mathrm{Fe}_{3} \mathrm{O}_{4}$ surfaces may include two different sites of $\mathrm{Cu}-\mathrm{O}$ (cupric oxide) and $\mathrm{Fe}-\mathrm{O}$ (iron oxide), and the adsorption capability of strong and weak adsorption sites were determined to be 34.43 and $10.05 \mathrm{mg} \mathrm{g}^{-1}$ respectively.

Comparatively, Cu-doped $\mathrm{Fe}_{3} \mathrm{O}_{4}$ showed higher adsorption capacity towards $\mathrm{Sb}$ (III) and $\mathrm{Sb}(\mathrm{v})$ than the non-doped $\mathrm{Fe}_{3} \mathrm{O}_{4}$, and this may be mainly attributed to its low particle diameter, high surface area, and more and powerful adsorption site. Table 3 further compares the adsorption capacity of these two adsorbents with other reported adsorbents. Cu-doped $\mathrm{Fe}_{3} \mathrm{O}_{4}$ may not be the best adsorbent to adsorb $\mathrm{Sb}$; however, its magnetic character with relatively high adsorption density enables it as a promising alternative adsorbent for $\mathrm{Sb}$ removal.

3.2.3 Effects of solution $\mathrm{pH}$ and ionic strength. Solution $\mathrm{pH}$ has influence on adsorbent surface charge and Sb species distribution, and affects the adsorption processes thereafter. The species distribution of $\mathrm{Sb}(\mathrm{III})$ and $\mathrm{Sb}(\mathrm{v})$ over a wide $\mathrm{pH}$ range from 2.0 to 12.0, as indicated from Visual MINTEQ software modeling, are illustrated in Fig. $\mathrm{S} 3, \dagger$ and $\mathrm{Sb}(\mathrm{OH})_{3}$ and $\mathrm{Sb}(\mathrm{OH})_{6}{ }^{-}$ were the dominant species of $\mathrm{Sb}(\mathrm{III})$ and $\mathrm{Sb}(\mathrm{v})$ at $\mathrm{pH}$ 7.0.59 Fig. $\mathrm{S} 4 \uparrow$ illustrates the adsorption of $\mathrm{Sb}$ (III) and $\mathrm{Sb}$ (v) onto $\mathrm{Fe}_{3} \mathrm{O}_{4}$ and $\mathrm{Cu}$-doped $\mathrm{Fe}_{3} \mathrm{O}_{4}$ in wide $\mathrm{pH}$ ranges at IS of 0.01 and $0.1 \mathrm{M}$ $\mathrm{KNO}_{3}$. The elevated $\mathrm{pH}$ benefited the adsorption of $\mathrm{Sb}(\mathrm{III})$, whereas inhibited that of $\mathrm{Sb}(\mathrm{v})$ onto both $\mathrm{Fe}_{3} \mathrm{O}_{4}$ and $\mathrm{Cu}$-doped
$\mathrm{Fe}_{3} \mathrm{O}_{4}$. The adsorption density of $\mathrm{Sb}$ (III) increased from 3.32 $\mathrm{mg} \mathrm{g}^{-1}$ to $36.01 \mathrm{mg} \mathrm{g}^{-1}$ for $\mathrm{Fe}_{3} \mathrm{O}_{4}$ and from $40.92 \mathrm{mg} \mathrm{g}^{-1}$ to $51.58 \mathrm{mg} \mathrm{g}^{-1}$ for $\mathrm{Cu}$-doped $\mathrm{Fe}_{3} \mathrm{O}_{4}$ with elevated $\mathrm{pH}$ from 3.0 to 7.0 [Fig. S4(a) †]. Comparatively, the adsorption of $\mathrm{Sb}(\mathrm{v})$ showed opposite trends and decreased from $33.75 \mathrm{mg} \mathrm{g}^{-1}$ to $9.52 \mathrm{mg}$ $\mathrm{g}^{-1}$ for $\mathrm{Fe}_{3} \mathrm{O}_{4}$ and from $81.79 \mathrm{mg} \mathrm{g}^{-1}$ to $20.27 \mathrm{mg} \mathrm{g}^{-1}$ for $\mathrm{Cu}-$ doped $\mathrm{Fe}_{3} \mathrm{O}_{4}$ with elevated $\mathrm{pH}$ from 3.0 to 10.0 [Fig. S4(b)广]. A similar phenomenon of $\mathrm{pH}$ effects is observed in the case of adsorption of $\mathrm{Sb}(\mathrm{III})$ and $\mathrm{Sb}(\mathrm{v})$ onto nano-size zero-valent iron (nZVI) ${ }^{60}$ and ferric manganese binary oxide (FMBO). ${ }^{61}$ The promoted $\mathrm{Sb}(\mathrm{v})$ adsorption at elevated $\mathrm{pH}$ could be attributed to the formation of inner-sphere complex on the surfaces of $\mathrm{Fe}_{3} \mathrm{O}_{4}$ and $\mathrm{Cu}$-doped $\mathrm{Fe}_{3} \mathrm{O}_{4} \cdot{ }^{10}$ Furthermore with elevated $\mathrm{IS}_{\mathrm{KNO}_{3}}$ from 0.01 to $0.1 \mathrm{M}$, the adsorption of $\mathrm{Sb}(\mathrm{III})$ and $\mathrm{Sb}(\mathrm{v})$ was slightly affected in wide $\mathrm{pH}$ range, and this supported the involvement of inner-sphere complex in adsorption. Ackermann et al. ${ }^{62}$ also confirmed the formation of inner-sphere complex on Fe oxide surfaces by extended X-ray adsorption fine structure (EXAFS) analysis.

The zeta potential in the various solution $\mathrm{pH}$ is presented in Fig. 6 for $\mathrm{Fe}_{3} \mathrm{O}_{4}$ and $\mathrm{Cu}$-doped $\mathrm{Fe}_{3} \mathrm{O}$. The zeta potential of $\mathrm{Fe}_{3} \mathrm{O}_{4}$ decreased from 25.1 to $-42.5 \mathrm{mV}$ and that of $\mathrm{Cu}$-doped $\mathrm{Fe}_{3} \mathrm{O}_{4}$ from 3.23 to $-22.5 \mathrm{mV}$ with elevated $\mathrm{pH}$ from 3.0 to 10.0 , and their $\mathrm{pH}_{\mathrm{pzc}}(\mathrm{pH}$ at which the surface is zero-charged) were both near to 4.5 . The more negatively-charged surfaces increased the repulsive forces and inhibited the adsorption of anionic 
Table 3 Comparison of $\mathrm{Sb}(\mathrm{II})$ and $\mathrm{Sb}(\mathrm{V})$ sorption capacity with different sorbents

\begin{tabular}{|c|c|c|c|c|c|c|}
\hline \multirow[b]{2}{*}{ Adsorbents } & \multicolumn{2}{|c|}{$\begin{array}{l}\text { Sorption capacity } \\
\left(\mathrm{mg} \mathrm{g}^{-1}\right)\end{array}$} & \multirow{2}{*}{$\begin{array}{l}\text { Initial Sb concentrations } \\
\left(\mathrm{mg} \mathrm{L}^{-1}\right)\end{array}$} & \multirow{2}{*}{$\begin{array}{l}\text { Adsorbent doses } \\
\left(\mathrm{mg} \mathrm{L}^{-1}\right)\end{array}$} & \multirow[b]{2}{*}{$\mathrm{pH}$} & \multirow[b]{2}{*}{ Reference } \\
\hline & $\mathrm{Sb}$ (III) & $\mathrm{Sb}(\mathrm{v})$ & & & & \\
\hline Cyanobacteria & 4.9 & - & 10 & $0.04-1.0$ & 4 & 51 \\
\hline Graphene oxide & 36.5 & - & 10 & 600 & 7 & 52 \\
\hline MWCNTs & 0.4 & - & 4 & 200 & 7 & 53 \\
\hline QFGO & $2.9-6.1$ & - & 10 & 20000 & - & 56 \\
\hline Diatomite & 35.2 & - & $10-400$ & 4000 & 6 & 57 \\
\hline $\mathrm{ZCN}$ & 70.8 & 57.2 & $10-500$ & 1000 & 7 & 58 \\
\hline $\mathrm{Fe}_{3} \mathrm{O}_{4}$ & 30.92 & 7.07 & 50 & 200 & 7 & This study \\
\hline $\mathrm{Cu}$-doped $\mathrm{Fe}_{3} \mathrm{O}_{4}$ & 43.55 & 34.46 & 50 & 200 & 7 & \\
\hline
\end{tabular}

$\mathrm{Sb}(\mathrm{OH})_{6}{ }^{-}$, which was thermodynamically stable in $\mathrm{pH}$ 4.0-10.0 [Fig. S3(b)†]. Comparatively, the negative surface at higher $\mathrm{pH}$ showed less effect on the adsorption of non-ionic $\mathrm{Sb}(\mathrm{OH})_{3}$, and the observed $\mathrm{pH}$-dependent adsorption of $\mathrm{Sb}$ (III) may be attributed to the involvement of different mechanisms besides electrostatic attraction. Fig. 6 also compares the zeta potential of these adsorbents before and after sorbing $\mathrm{Sb}(\mathrm{III})$ and $\mathrm{Sb}(\mathrm{v})$. The adsorption of $\mathrm{Sb}$ (III) decreased zeta potential more significantly than that of $\mathrm{Sb}(\mathrm{v})$, and this indicated the strong interaction between $\mathrm{Sb}$ (III) and the surfaces of both adsorbents. The significant $\mathrm{pH}_{\mathrm{pzc}}$ shift inferred the involvement of specific adsorption in $\mathrm{Sb}$ adsorption besides electrostatic interaction. ${ }^{63}$

3.2.4 Effect of co-existing anions. In natural water systems, the widely presented anions may occupy the sorption sites and inhibit the removal of antimony. The co-existing species, i.e., $\mathrm{PO}_{4}{ }^{3-}, \mathrm{SO}_{4}{ }^{2-}$, and $\mathrm{CO}_{3}{ }^{2-}$, inhibited the adsorption of $\mathrm{Sb}(\mathrm{III})$ and $\mathrm{Sb}(\mathrm{v})$ onto $\mathrm{Fe}_{3} \mathrm{O}_{4}$ and $\mathrm{Cu}$-doped $\mathrm{Fe}_{3} \mathrm{O}_{4}$ in the order of $\mathrm{PO}_{4}{ }^{3-}>$ $\mathrm{SO}_{4}{ }^{2-}>\mathrm{CO}_{3}{ }^{2-}$ (Fig. S6 + ). The carbonate and sulfate at concentrations of above $10 \mathrm{mM}$, which may be their maximum concentrations in natural waters, showed limited effects on antimony adsorption. Comparatively, phosphate at the same level showed more significant inhibition and its adverse effect

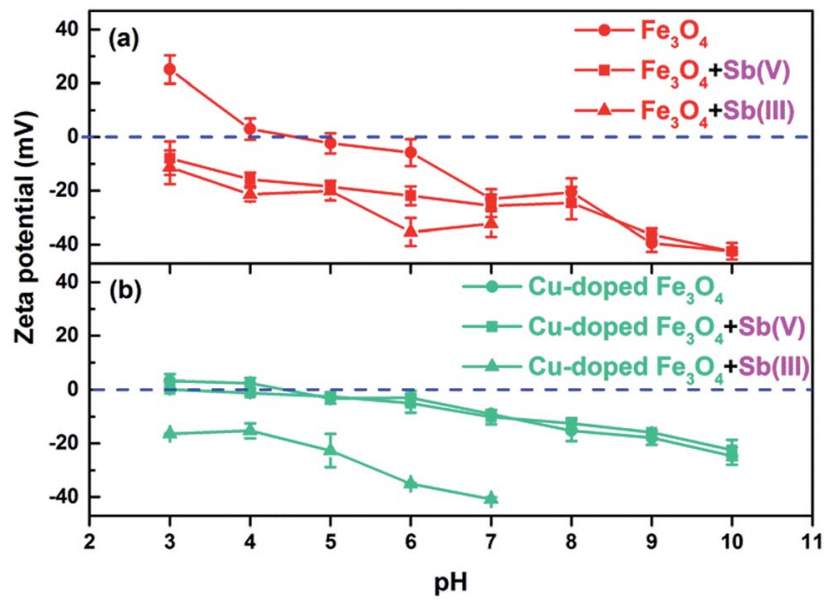

Fig. 6 The variation of the zeta potential of (a) $\mathrm{Cu}$-doped $\mathrm{Fe}_{3} \mathrm{O}_{4}$ and (b) $\mathrm{Fe}_{3} \mathrm{O}_{4}$ before and after the adsorption of $\mathrm{Sb}(\mathrm{II})$ and $\mathrm{Sb}(\mathrm{V})$. on the adsorption has been widely reported. ${ }^{64,65}$ Phosphate, arsenate, and antimonate are oxyacids of main $\mathrm{V}$ group elements with similar chemical structure, and they preferred to occupy the same sorbing sites. Quantitatively, phosphate at extremely high concentration of $10 \mathrm{mM}$ decreased the $\mathrm{Sb}(\mathrm{III})$ and $\mathrm{Sb}(\mathrm{v})$ removal by $50.1 \%$ and $18.2 \%$ for $\mathrm{Fe}_{3} \mathrm{O}_{4}$ and by $14.1 \%$ and $58.6 \%$ for $\mathrm{Cu}$-doped $\mathrm{Fe}_{3} \mathrm{O}_{4}$. In considering that phosphate concentrations in most natural waters are below $1 \mathrm{mM}$, and the inhibitive effect on $\mathrm{Sb}$ adsorption may be ignored accordingly.

\subsection{Proposed mechanism of $\mathrm{Sb}(\mathrm{III})$ and $\mathrm{Sb}(\mathrm{v})$ adsorption}

To investigate the mechanisms involved in the adsorption of antimony, the XPS spectra of the $\mathrm{Fe}_{3} \mathrm{O}_{4}$ and $\mathrm{Cu}$-doped $\mathrm{Fe}_{3} \mathrm{O}_{4}$ after adsorbing $\mathrm{Sb}(\mathrm{III}) / \mathrm{Sb}(\mathrm{v})$ at $\mathrm{pH} 7.0$ were collected and the $\mathrm{O} 1 \mathrm{~s}$ and $\mathrm{Sb} 3 \mathrm{~d}$ spectra are illustrated in Fig. 7.

The spectra of $\mathrm{Sb} 3 \mathrm{~d}_{3 / 2}$ did not overlap with $\mathrm{O} 1 \mathrm{~s}$ and was

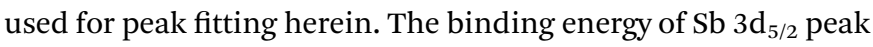
is set by the $\mathrm{Sb} 3 \mathrm{~d}_{3 / 2}$ peak according to the spin-orbit splitting $(\Delta=9.39 \mathrm{eV})$.

The adsorption of either $\mathrm{Sb}(\mathrm{III})$ or $\mathrm{Sb}(\mathrm{v})$ contributed to the appearance of new $\mathrm{Sb} 3 \mathrm{~d}_{3 / 2}$ peaks with the binding energy of $540.0 \mathrm{eV}$ and $540.3 \mathrm{eV}$ in the spectra of $\mathrm{Fe}_{3} \mathrm{O}_{4}$ and $\mathrm{Cu}$-doped $\mathrm{Fe}_{3} \mathrm{O}_{4}$, respectively. Interestingly, the $\mathrm{Sb} 3 \mathrm{~d}_{3 / 2}$ showed the same binding energy in regardless of the initial $\mathrm{Sb}$ species of either $\mathrm{Sb}(\mathrm{III})$ or $\mathrm{Sb}(\mathrm{v})$. The binding energy of $\mathrm{Sb} 3 \mathrm{~d}_{3 / 2}$ in $\mathrm{Sb}_{2} \mathrm{O}_{3}$ and $\mathrm{Sb}_{2} \mathrm{O}_{5}$ was reported to be 539.6 and $540.2 \mathrm{eV}$, respectively. ${ }^{66}$ The dominant $\mathrm{Sb}$ species on the surfaces of both adsorbents was determined to be $\mathrm{Sb}(\mathrm{v})$ and the oxidation of $\mathrm{Sb}$ (III) to $\mathrm{Sb}(\mathrm{v})$ was inferred to involve in the adsorption of $\mathrm{Sb}$ (III) on both adsorbents. The slight difference in the BE $(0.3$ $\mathrm{eV}$ ) of $\mathrm{Sb} 3 \mathrm{~d}_{3 / 2}$ between these two adsorbents may be attributed to the different bonding state of antimony on their surfaces. The heterogeneous oxidation of $\mathrm{Sb}$ (III) on the surfaces of metal oxides has been reported in literature: Leuz et al. reported that the adsorbed $\mathrm{Sb}$ (III) may be oxidized by aqueous oxygen and goethite acts as a catalyst to enhance $\mathrm{Sb}(\mathrm{III})$ oxidation. ${ }^{67}$ Wang et al. also reported that $\mathrm{As}(\mathrm{III})$ is efficiently oxidized to $\mathrm{As}(\mathrm{v})$ by $\mathrm{O}_{2}$ on $\mathrm{Cu}$-doped $\mathrm{Fe}_{3} \mathrm{O}_{4}$ surfaces. ${ }^{26}$ The elements with high valence, e.g. $\mathrm{Mn}^{\mathrm{IV}}, \mathrm{Fe}^{\mathrm{III}}$, are good electron acceptors and may participate in the oxidation of $\mathrm{Sb}(\mathrm{III})$ to $\mathrm{Sb}(\mathrm{v}) \cdot{ }^{61,68}$ Moreover, 


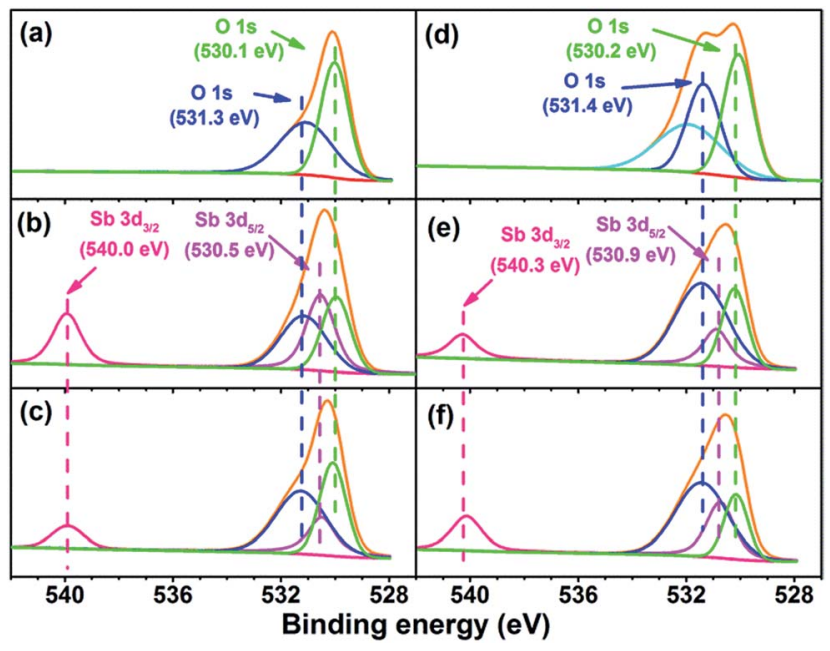

Fig. $7 \mathrm{O}$ 1s and $\mathrm{Sb} 3 \mathrm{~d}$ XPS spectra of [(a) $\mathrm{Fe}_{3} \mathrm{O}_{4}$, (b) $\mathrm{Fe}_{3} \mathrm{O}_{4}+\mathrm{Sb}$ (III), (c) $\mathrm{Fe}_{3} \mathrm{O}_{4}+\mathrm{Sb}(\mathrm{v})$, (d) $\mathrm{Cu}$-doped $\mathrm{Fe}_{3} \mathrm{O}_{4}$, (e) $\mathrm{Cu}$-doped $\mathrm{Fe}_{3} \mathrm{O}_{4}+\mathrm{Sb}$ (III), (f) $\mathrm{Cu}$-doped $\left.\mathrm{Fe}_{3} \mathrm{O}_{4}+\mathrm{Sb}(\mathrm{v})\right]$.

$\mathrm{Cu}^{\mathrm{II}}$ has strong oxidant capacities and its compounds are commonly used as oxidation agents. ${ }^{69-71}$ So the question is: what role does copper play within $\mathrm{Sb}(\mathrm{III})$ oxidation process, catalyst or oxidant?

To further confirm the oxidation of $\mathrm{Sb}(\mathrm{III})$ by $\mathrm{Cu}$-doped $\mathrm{Fe}_{3} \mathrm{O}_{4}$, the species distribution and transformation of $\mathrm{Sb}$ after adsorption was quantitatively analyzed in aerobic $\left(\mathrm{O}_{2}\right.$ purging) and anaerobic $\left(\mathrm{N}_{2}\right.$-purging) systems. After the adsorption of $\mathrm{Sb}$ (III) on these two adsorbents at $\mathrm{pH} 7.0$, the concentrations of aqueous $\mathrm{Sb}$ (III) [ $\left.\mathrm{Sb}(\mathrm{III})_{\text {aqueous}}\right]$ and $\mathrm{Sb}(\mathrm{v})$ $\left[\mathrm{Sb}(\mathrm{v})_{\text {aqueous }}\right]$ are illustrated in Fig. 8(a). In the presence of $\mathrm{Fe}_{3} \mathrm{O}_{4}$, the oxidation of $\mathrm{Sb}(\mathrm{III})$ was rather slight and the ratios of $\mathrm{Sb}(\mathrm{v})$ to total $\mathrm{Sb}$ was below $10 \%$ in solution. Comparatively, the oxidation of $\mathrm{Sb}(\mathrm{III})$ was significant in the presence of $\mathrm{Cu}$ doped $\mathrm{Fe}_{3} \mathrm{O}_{4}$, and $\mathrm{Sb}(\mathrm{v})$ was the dominant species with the ratios of over $50 \%$ either in bulk solution and on $\mathrm{Cu}$-doped $\mathrm{Fe}_{3} \mathrm{O}_{4}$ surface. Additionally, the oxidation of $\mathrm{Sb}$ (III) occurred in both $\mathrm{N}_{2}$ - and $\mathrm{O}_{2}$-purging systems and the ratios of aqueous $\mathrm{Sb}(\mathrm{v})$ to total $\mathrm{Sb}$ were observed to be $62.3 \%$ and $58.9 \%$, respectively. In the absence of $\mathrm{Cu}$-doped $\mathrm{Fe}_{3} \mathrm{O}_{4}$, the oxidation of $\mathrm{Sb}$ (III) can barely be achieved in either $\mathrm{N}_{2}$ - or $\mathrm{O}_{2}$-purging systems. These results indicate the significance of $\mathrm{Cu}$-doped $\mathrm{Fe}_{3} \mathrm{O}_{4}$ on $\mathrm{Sb}$ (III) oxidation. Our results are in agreement with the literature that ambient $\mathrm{O}_{2}$ was unlikely to be a significant oxidant in oxidation of $\mathrm{Sb}(\mathrm{III})$ to $\mathrm{Sb}(\mathrm{v}) .{ }^{72}$ Moreover, higher $\mathrm{pH}$ value was found to greatly enhance oxidation process by $\mathrm{Cu}-$ doped $\mathrm{Fe}_{3} \mathrm{O}_{4}$. Almost all aqueous $\mathrm{Sb}$ (III) can be oxidized to $\mathrm{Sb}(\mathrm{v})$ in presence of $\mathrm{Cu}$-doped $\mathrm{Fe}_{3} \mathrm{O}_{4}$ at $\mathrm{pH}$ 11.0; however, very little $\mathrm{Sb}(\mathrm{III})$ could be oxidized using non-doped $\mathrm{Fe}_{3} \mathrm{O}_{4}$.

On the other hand, the $\mathrm{Cu} 2 \mathrm{p}_{2 / 3}$ peak at $942.3 \mathrm{eV}$ disappeared after the adsorption of $\mathrm{Sb}(\mathrm{III})$ (Fig. $\mathrm{S} 1 \dagger$ ), and this supported the reduction of $\mathrm{Cu}$ (II) to that with lower chemical valence, i.e., $\mathrm{Cu}^{0}, \mathrm{Cu}^{\mathrm{I}}$. Furthermore, the thermodynamic calculation also indicated that $\mathrm{Sb}(\mathrm{III})$ may be oxidized to $\mathrm{Sb}(\mathrm{v})$ by $\mathrm{Cu}^{\mathrm{II}}$, and the possible chemical reactions eqn (11) and (12) are given as follows:
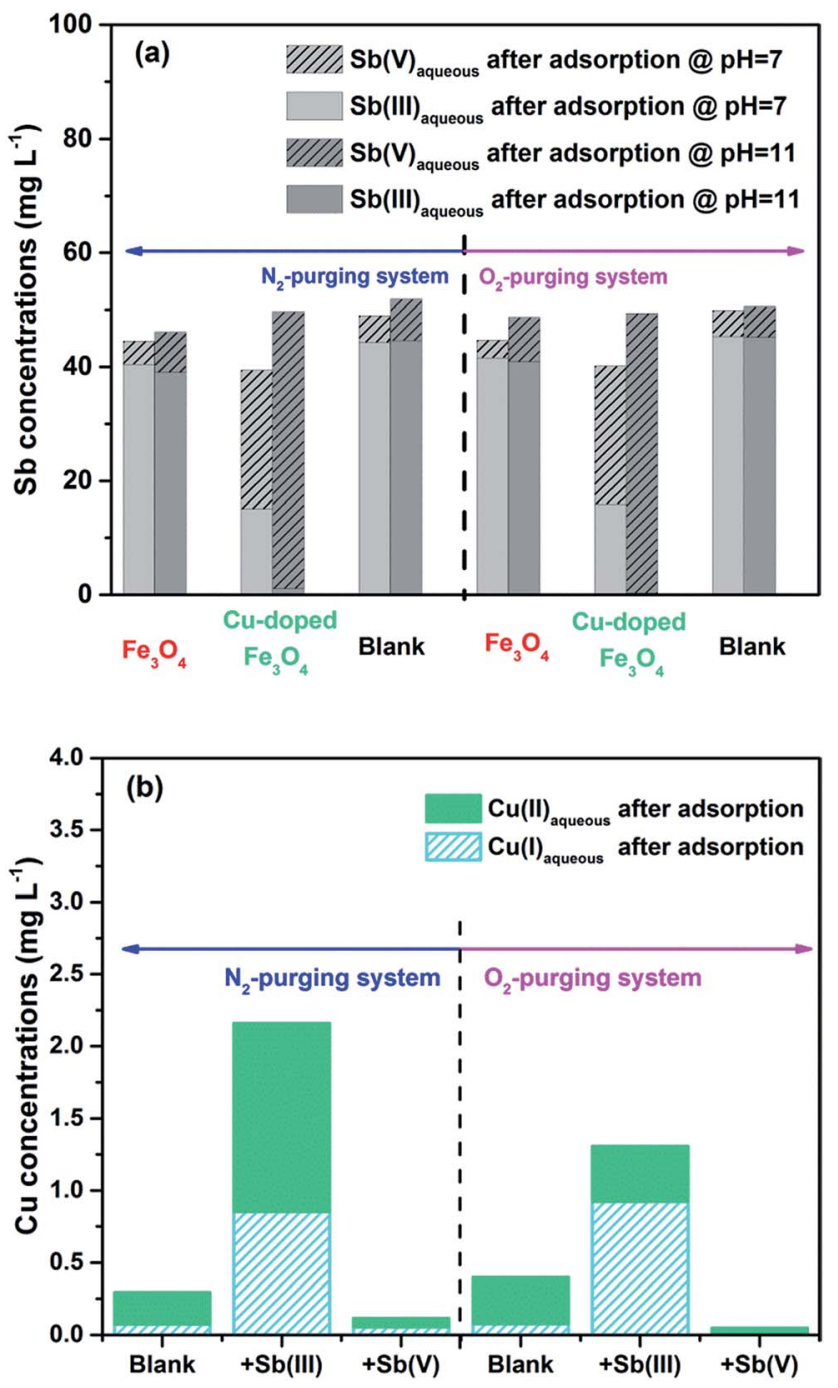

Fig. 8 (a) Species distribution of antimony in solution involved in the adsorption of $\mathrm{Sb}(\mathrm{II})$ onto $\mathrm{Fe}_{3} \mathrm{O}_{4}$ and $\mathrm{Cu}$-doped $\mathrm{Fe}_{3} \mathrm{O}_{4}$ at different $\mathrm{pH}$ (b) species distribution of copper in solution adsorption involved in the adsorption of $\mathrm{Sb}(\mathrm{II})$ and $\mathrm{Sb}(\mathrm{V})$ onto $\mathrm{Cu}$-doped $\mathrm{Fe}_{3} \mathrm{O}_{4}$.

$$
\begin{aligned}
& 2 \mathrm{CuFe}_{2} \mathrm{O}_{4}+2 \mathrm{Sb}^{\mathrm{III}}(\mathrm{OH})_{3}=\mathrm{Sb}_{2} \mathrm{O}_{5}+2 \mathrm{Cu}^{0}+\mathrm{Fe}_{2} \mathrm{O}_{3}+3 \mathrm{H}_{2} \mathrm{O} \\
& \Delta G=-4.055 \mathrm{kcal}, \log K=2.97 @ 25{ }^{\circ} \mathrm{C}
\end{aligned}
$$

$4 \mathrm{CuFe}_{2} \mathrm{O}_{4}+2 \mathrm{Sb}^{\mathrm{III}}(\mathrm{OH})_{3}=\mathrm{Sb}_{2} \mathrm{O}_{5}+2 \mathrm{Cu}_{2}^{\mathrm{I}} \mathrm{O}+\mathrm{Fe}_{2} \mathrm{O}_{3}+3 \mathrm{H}_{2} \mathrm{O}$, $\Delta G=-13.504 \mathrm{kcal}, \log K=9.90 @ 25{ }^{\circ} \mathrm{C}$

It was noted that $\mathrm{CuFe}_{2} \mathrm{O}_{4}$ was viewed as the dominant constituent of Cu-doped $\mathrm{Fe}_{3} \mathrm{O}_{4}$ and $\mathrm{Sb}(\mathrm{OH})_{3}$ as the main $\mathrm{Sb}$ (III) species at pH 7.0 (Fig. S3†). The higher equilibrium constant $(K)$ is relative to stronger intensity toward the products. The two copper species of $\mathrm{Cu}^{\mathrm{I}}$ and $\mathrm{Cu}^{0}$ may be produced; however, $\mathrm{Cu}^{\mathrm{I}}$ may be the dominant product as indicated from the $K$ values.

To further illustrate the possible oxidation and reduction reactions involve in, the concentrations of aqueous copper(I)/(II) before and after the adsorption of $\mathrm{Sb}(\mathrm{III})$ and $\mathrm{Sb}(\mathrm{v})$ onto $\mathrm{Cu}$ doped $\mathrm{Fe}_{3} \mathrm{O}_{4}$ were quantitatively analyzed [Fig. 8(b)]. It was observed that the concentrations of aqueous copper in the control experiments were extremely low to be below $0.4 \mathrm{mg} \mathrm{L}^{-1}$. 


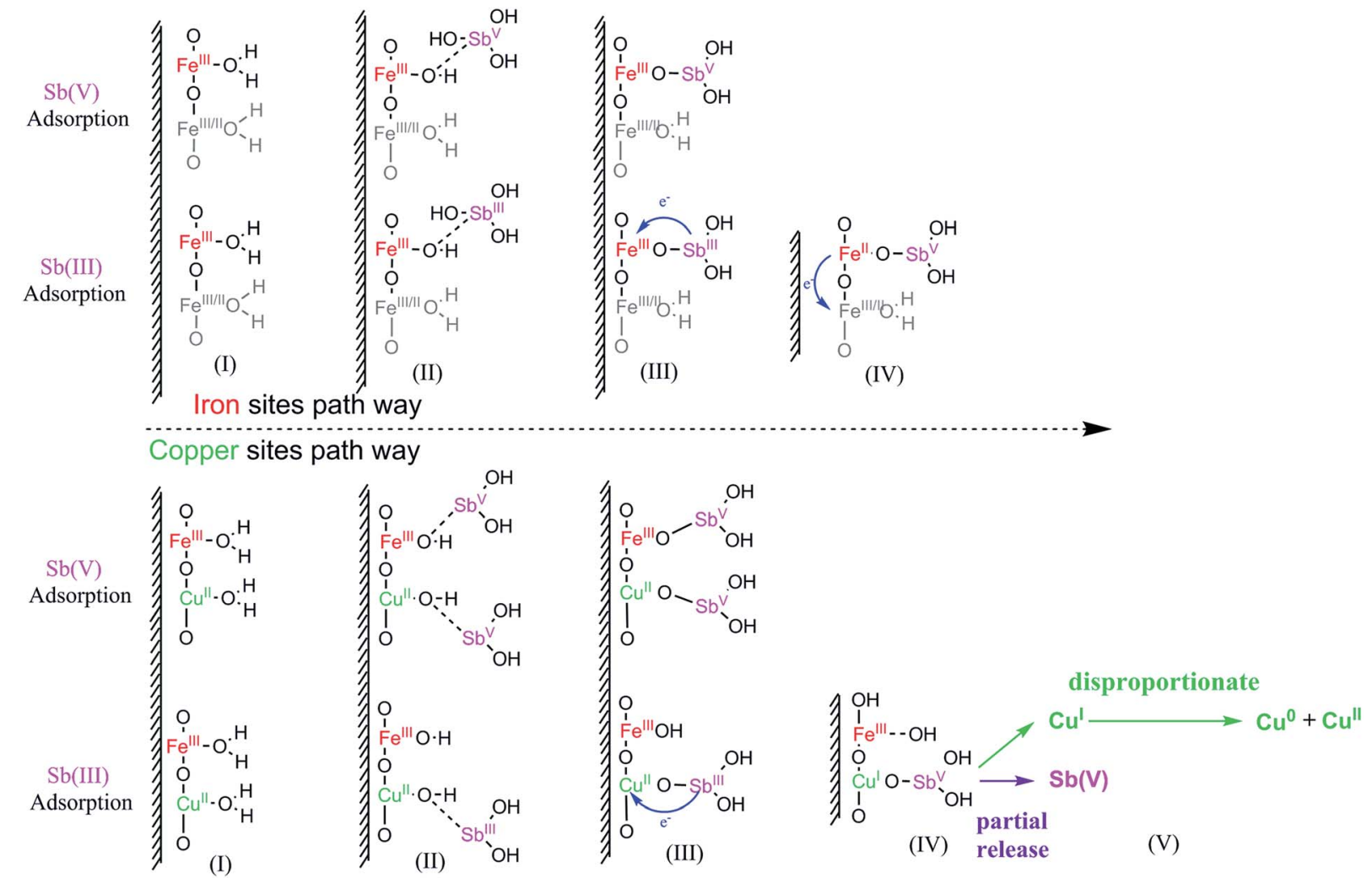

Fig. 9 Proposed mechanisms for the adsorption of $\mathrm{Sb}(\mathrm{II})$ and $\mathrm{Sb}(\mathrm{V})$ onto $\mathrm{Fe}_{3} \mathrm{O}_{4}$ and $\mathrm{Cu}$-doped $\mathrm{Fe}_{3} \mathrm{O}_{4}$.

The adsorption of $\mathrm{Sb}(\mathrm{v})$ slightly decreases the concentrations to as low as $0.15 \mathrm{mg} \mathrm{\textrm {L } ^ { - 1 }}$. Comparatively, in $\mathrm{Sb}(\mathrm{III})$ adsorption systems the concentrations of dissolve $\mathrm{Cu}$ (total of $\mathrm{Cu}^{\mathrm{I}}$ and $\mathrm{Cu}^{\mathrm{II}}$ ) increased significantly to 1.3 and $2.1 \mathrm{mg} \mathrm{L}^{-1}$ in $\mathrm{O}_{2^{-}}$and $\mathrm{N}_{2^{-}}$ purging systems, owing to the heterogeneous electron transfer from $\mathrm{Sb}$ (III) to $\mathrm{Cu}$-doped $\mathrm{Fe}_{3} \mathrm{O}_{4}$ surface. However, the leaching copper into the aqueous phase could exceed the drinking water limit of $2.0 \mathrm{mg} \mathrm{L}^{-1}$ and we need to remove $\mathrm{Cu}$ after $\mathrm{Sb}$ removal. ${ }^{46}$ Fortunately, there are cheap and reliable methods that could also be used to remove $\mathrm{Cu}$ from water e.g. chemical precipitation, ${ }^{73}$ sorption, ${ }^{74}$ and ultrafiltration. ${ }^{75}$

After the oxidation of $\mathrm{Sb}(\mathrm{III})$, the aqueous $\mathrm{Sb}(\mathrm{v})$ concentrations increased, owing to the release of the formed $\mathrm{Sb}(\mathrm{v})$ and $\mathrm{Cu}(\mathrm{I})$ from $\mathrm{Cu}$-doped $\mathrm{Fe}_{3} \mathrm{O}_{4}$ surface to solution. And then, copper(I) ions in solution disproportionate to give copper(II) ions and a precipitate of copper. As some of the $\mathrm{Sb}$ (III) oxidation by $\mathrm{O}_{2}$ in oxygen-rich conditions, the $\mathrm{Cu}$-doped $\mathrm{Fe}_{3} \mathrm{O}_{4}$ can release less copper than in oxygen-deficiency conditions.

On the basis of these results, the possible mechanisms involved in the adsorption and oxidation of $\mathrm{Sb}(\mathrm{III})$ and the release of $\mathrm{Sb}(\mathrm{v})$ on the surfaces of $\mathrm{Fe}_{3} \mathrm{O}_{4}$ and $\mathrm{Cu}$-doped $\mathrm{Fe}_{3} \mathrm{O}_{4}$ were proposed and illustrated in Fig. 9:

As for the "iron-based pathway" (for $\mathrm{Fe}_{3} \mathrm{O}_{4}$ and $\mathrm{Cu}$-doped $\mathrm{Fe}_{3} \mathrm{O}_{4}$ ), the adsorption of $\mathrm{Sb}(\mathrm{III}) / \mathrm{Sb}(\mathrm{v})$ included following major reactions:

(I) Surface dissolution, hydrolysis, and the formation of surface hydroxyl groups;

(II) Adsorption of $\mathrm{Sb}(\mathrm{III}) / \mathrm{Sb}$ (v) onto $\equiv \mathrm{Fe}^{\mathrm{III}}-\mathrm{O}$ sites;
(III) Electron transfer from $\mathrm{Sb}$ (III) to $\mathrm{Fe}(\mathrm{III})$ and heterogeneous oxidation of $\mathrm{Sb}$ (III) (slight);

(IV) Electron transfer from $\mathrm{Fe}(\mathrm{II})$ to $\mathrm{Fe}(\mathrm{III} / \mathrm{II})$.

As for the "copper-based pathway" (for $\mathrm{Cu}$-doped $\mathrm{Fe}_{3} \mathrm{O}_{4}$ only), the adsorption of $\mathrm{Sb}$ (III) mainly included the following reactions:

(I) Surface dissolution and hydrolysis and the formation of surface hydroxyl groups;

(II) Adsorption of $\mathrm{Sb}(\mathrm{III}) / \mathrm{Sb}$ (v) onto $\equiv \mathrm{Cu}^{\mathrm{II}}-\mathrm{O}$ sites;

(III) Electron transfer from $\mathrm{Sb}$ (III) to $\mathrm{Cu}(\mathrm{II})$ and heterogeneous oxidation of $\mathrm{Sb}$ (III) (significant);

(IV) Release of $\mathrm{Cu}(\mathrm{I})$ and $\mathrm{Sb}(\mathrm{v})$ into solution;

(V) $\mathrm{Cu}(\mathrm{I})$ disproportionate to give copper(II) ions and a precipitate of copper.

\section{Conclusions}

The doping of $\mathrm{Cu}$ into $\mathrm{Fe}_{3} \mathrm{O}_{4}$ by solvothermal method improves the adsorption capability towards $\mathrm{Sb}(\mathrm{III})$ and $\mathrm{Sb}(\mathrm{v})$ as compared to the non-doped $\mathrm{Fe}_{3} \mathrm{O}_{4}$. The maximum adsorption capacity of Cu-doped $\mathrm{Fe}_{3} \mathrm{O}_{4}$ is determined to be $43.55 \mathrm{mg} \mathrm{g}^{-1}$ for $\mathrm{Sb}$ (III) and $34.46 \mathrm{mg} \mathrm{g}^{-1}$ for $\mathrm{Sb}(\mathrm{v})$ at $\mathrm{pH}$ 7.0. The elevated $\mathrm{pH}$ is beneficial to the adsorption of $\mathrm{Sb}(\mathrm{III})$, whereas inhibitive to that of $\mathrm{Sb}(\mathrm{v})$. The co-existing $\mathrm{PO}_{4}{ }^{3-}$ shows adverse effect on $\mathrm{Sb}$ removal; however, the inhibiting extent at $1 \mathrm{mM}$ is relatively low. Cu doping shows little effect on the crystalline of $\mathrm{Fe}_{3} \mathrm{O}_{4}$ but remarkably increases the $S_{\mathrm{BET}}$ from 9.66 to $67.20 \mathrm{~m}^{2} \mathrm{~g}^{-1}$, and this effect plays an important role in the enhanced $\mathrm{Sb}$ removal. Additionally, $\mathrm{Cu}-$ 
doping greatly increases the oxidative ability towards $\mathrm{Sb}$ (III) and enables the heterogeneous electron transfer from $\mathrm{Sb}$ (III) to $\mathrm{Cu}(\mathrm{II})$. The electron transfer from $\mathrm{Sb}$ (III) to $\mathrm{Fe}$ (III) on $\equiv \mathrm{Fe}^{\mathrm{III}}-\mathrm{O}$ sites might occur; however, the extent is rather weak. The formed $\mathrm{Sb}(\mathrm{v})$ and $\mathrm{Cu}(\mathrm{I})$ tends to release from adsorbents surfaces partially, and $\mathrm{Cu}(\mathrm{I})$ may disproportionate to give copper(II) ions and a precipitate of copper. Cu-doped $\mathrm{Fe}_{3} \mathrm{O}_{4}$ shows good magnetic character and high adsorption capacity, and may be promising to remove antimony from the contaminated water.

\section{Acknowledgements}

This work was supported by Natural Science Foundation of China (Grant no. 51422813) and Major Science and Technology Program for Water Pollution Control and Treatment (2012ZX07414-001). Author Ruiping Liu gratefully acknowledges the support of the Beijing Nova Program (2013054).

\section{References}

1 N. M. I. Center, Minerals Yearbook, U.S. Government Printing Office, 2015.

2 T. Bacquart, S. Frisbie, E. Mitchell, L. Grigg, C. Cole, C. Small and B. Sarkar, Sci. Total Environ., 2015, 517, 232-245.

3 C. A. Abin and J. T. Hollibaugh, Environ. Sci. Technol., 2014, 48, 681-688.

4 J. K. Edzwald, Water Quality \& Treatment: A Handbook on Drinking Water, McGraw-Hill Education, New York, 6th edn, 2010.

5 X. Guo, Z. Wu and M. He, Water Res., 2009, 43, 4327-4335.

6 M. Kang, M. Kawasaki, S. Tamada, T. Kamei and Y. Magara, Desalination, 2000, 131, 293-298.

7 A. T. Kuhn and R. W. Houghton, J. Appl. Electrochem., 1974, 4, 69-73.

8 X. Guo, Z. Wu, M. He, X. Meng, X. Jin, N. Qiu and J. Zhang, J. Hazard. Mater., 2014, 276, 339-345.

9 A. G. Ilgen and T. P. Trainor, Environ. Sci. Technol., 2012, 46, 843-851.

10 E. Worch, Adsorption Technology in Water Treatment, de Gruyter, 2012.

11 M. Jia, J. W. Hu, J. Luo, S. M. Duan, Z. B. Li and C. Liu, Adv. Mater. Res., 2013, 779-780, 1600-1606.

12 Y. H. Xu, A. Ohki and S. Maeda, Adsorption of antimony(III) on goethite in the presence of competitive anions, Toxicol. Environ. Chem., 2001, 80, 133-144.

13 J. H. Xi, M. C. He, K. P. Wang and G. Z. Zhang, J. Geochem. Explor., 2013, 132, 201-208.

14 C. Shan, Z. Ma and M. Tong, J. Hazard. Mater., 2014, 268, 229-236.

15 R. D. Ambashta and M. Sillanpaa, J. Hazard. Mater., 2010, 180, 38-49.

16 X. B. Luo, C. C. Wang, S. L. Luo, R. Z. Dong, X. M. Tu and G. S. Zeng, Chem. Eng. J., 2012, 187, 45-52.

17 H. Hashimoto, T. Nishimura and Y. Umetsu, Mater. Trans., 2003, 44, 1624-1629.
18 X. L. Peng, F. Xu, W. Z. Zhang, J. Y. Wang, C. Zeng, M. J. Niu and E. Chmielewska, Colloids Surf., A, 2014, 443, 27-36.

19 Y. F. Shen, J. Tang, Z. H. Nie, Y. D. Wang, Y. Ren and L. Zuo, Sep. Purif. Technol., 2009, 68, 312-319.

20 M. D. Simmons, N. Jones, D. J. Evans, C. Wiles, P. Watts, S. Salamon, M. Escobar Castillo, H. Wende, D. C. Lupascu and M. G. Francesconi, Lab Chip, 2015, 15, 3154-3162.

21 J. Mohapatra, A. Mitra, D. Bahadur and M. Aslam, CrystEngComm, 2013, 15, 524-532.

22 Y. J. Tu, C. F. You, C. K. Chang, T. S. Chan and S. H. Li, Chem. Eng. J., 2014, 244, 343-349.

23 S. Hashemian, A. Dehghanpor and M. Moghahed, J. Ind. Eng. Chem., 2015, 24, 308-314.

24 S. Sun, H. Zeng, D. B. Robinson, S. Raoux, P. M. Rice, S. X. Wang and G. Li, J. Am. Chem. Soc., 2004, 126, 273-279.

25 T. M. Thi, N. T. H. Trang and N. T. V. Anh, Appl. Surf. Sci., 2015, 340, 166-172.

26 T. Wang, W. C. Yang, T. T. Song, C. F. Li, L. Y. Zhang, H. Y. Wang and L. Y. Chai, RSC Adv., 2015, 5, 50011-50018.

27 H. Deng, X. Li, Q. Peng, X. Wang, J. Chen and Y. Li, Angew. Chem., 2005, 44, 2782-2785.

28 G. Zhang, H. Liu, R. Liu and J. Qu, J. Colloid Interface Sci., 2009, 335, 168-174.

29 X. W. Wang, X. K. Li, X. Zhang and S. H. Qian, J. Anal. At. Spectrom., 2014, 29, 1944-1948.

30 J. W. Moffett, R. G. Zika and R. G. Petasne, Anal. Chim. Acta, 1985, 175, 171-179.

31 H. B. Xue, M. D. S. Goncalves, M. Reutlinger, L. Sigg and W. Stumm, Environ. Sci. Technol., 1991, 25, 1716-1722.

32 S. E. Skrabalak, B. J. Wiley, M. Kim, E. V. Formo and Y. Xia, Nano Lett., 2008, 8, 2077-2081.

33 R. M. Cornell and U. Schwertmann, The Iron Oxides, 1996.

34 T. Yamashita and P. Hayes, Appl. Surf. Sci., 2008, 254, 24412449.

35 U. Schwertmann and R. M. Cornell, Iron Oxides in the Laboratory, Wiley-VCH Verlag GmbH, 2007.

36 K. S. W. Sing, D. H. Everett, R. A. W. Haul, L. Moscou, R. A. Pierotti, J. Rouquerol and T. Siemieniewska, Pure Appl. Chem., 1985, 57, 603-619.

37 J. S. Beveridge, J. R. Stephens, A. H. Latham and M. E. Williams, Anal. Chem., 2009, 81, 9618-9624.

38 D. Tripathy, A. O. Adeyeye, C. B. Boothroyd and S. Shannigrahi, J. Appl. Phys., 2008, 103, 07 F701.

39 Y. Z. Xiao, H. F. Liang and Z. C. Wang, Mater. Res. Bull., 2013, 48, 3910-3915.

40 L. Feng, M. Cao, X. Ma, Y. Zhu and C. Hu, J. Hazard. Mater., 2012, 217-218, 439-446.

41 W. Tang, Y. Su, Q. Li, S. Gao and J. K. Shang, Water Res., 2013, 47, 3624-3634.

42 Y. S. Ho and G. McKay, Process Saf. Environ. Prot., 1998, 76, 183-191.

43 Z. He, R. Liu, H. Liu and J. Qu, Environ. Eng. Sci., 2015, 32, 95-102.

44 I. S. McLintock, Nature, 1967, 216, 1204-1205.

45 M. Filella, N. Belzile and Y. W. Chen, Earth-Sci. Rev., 2002, 57, 125-176. 
46 W. H. Organization, Guidelines for drinking-water quality, 4th edn, 2011.

47 U. S. E. P. Agency, National Primary Drinking Water Regulations, 1996.

48 F. Y. Liu, X. C. Le, A. McKnight-Whitford, Y. L. Xia, F. C. Wu, E. Elswick, C. C. Johnson and C. Zhu, Environ. Geochem. Health, 2010, 32, 401-413.

49 D. G. Kinniburgh, Environ. Sci. Technol., 1986, 20, 895-904.

50 R. Sips, J. Chem. Phys., 1948, 16, 490-495.

51 F. C. Wu, F. H. Sun, S. Wu, Y. B. Yan and B. S. Xing, Chem. Eng. J., 2012, 183, 172-179.

52 X. Z. Yang, Z. Shi, M. Y. Yuan and L. S. Liu, J. Chem. Eng. Data, 2015, 60, 806-813.

53 M. A. Salam and R. M. Mohamed, Chem. Eng. Res. Des., 2013, 91, 1352-1360.

54 B. Verbinnen, C. Block, P. Lievens, A. Van Brecht and C. Vandecasteele, Waste Biomass Valorization, 2013, 4, 635645.

55 H. T. Lu, Z. L. Zhu, H. Zhang, J. Y. Zhu and Y. L. Qiu, Chem. Eng. J., 2015, 276, 365-375.

56 X. Z. Yang, Z. Shi and L. S. Liu, Chem. Eng. J., 2015, 260, 444453.

57 A. Sarı, D. Çıtak and M. Tuzen, Chem. Eng. J., 2010, 162, 521527.

58 J. Luo, X. Luo, J. Crittenden, J. Qu, Y. Bai, Y. Peng and J. Li, Environ. Sci. Technol., 2015, 49, 11115-11124.

59 J. Gustafsson, MINTEQA2 ver, ed. J. D. de Allison, D. S. Brown and K. J. Novo-Gradac, KTH Department of Land and Water Resources Engineering, Stockholm, Sweden, 2011, vol. 4, p. 1991.
60 C. M. Dai, Z. Zhou, X. F. Zhou and Y. L. Zhang, Water, Air, Soil Pollut., 2014, 225, 1799.

61 W. Xu, H. Wang, R. Liu, X. Zhao and J. Qu, J. Colloid Interface Sci., 2011, 363, 320-326.

62 S. Ackermann, J. Majzlan, R. Bolanz, R. Giere and M. Newville, Geochim. Cosmochim. Acta, 2008, 72, A5.

63 G. S. Zhang, H. J. Liu, R. P. Liu and J. H. Qu, J. Hazard. Mater., 2009, 168, 820-825.

64 Z. Hongshao and R. Stanforth, Environ. Sci. Technol., 2001, 35, 4753-4757.

65 X. Q. Wang, M. C. He, C. Y. Lin, Y. X. Gao and L. Zheng, Geochemistry, 2012, 72, 41-47.

66 R. Delobel, H. Baussart, J. M. Leroy, J. Grimblot and L. Gengembre, J. Chem. Soc., Faraday Trans. 1, 1983, 79, 879-891.

67 A. K. Leuz, H. Monch and C. A. Johnson, Environ. Sci. Technol., 2006, 40, 7277-7282.

68 P. Qi and T. Pichler, Chemosphere, 2016, 145, 55-60.

69 Z. Chen and T. J. Meyer, Angew. Chem., 2013, 52, 700-703.

70 C. W. Kenney and L. A. Uchida, US Pat., US4582613, 1986.

71 R. C. Smith, V. D. Reed and W. E. Hill, Phosphorus Sulfur Relat. Elem., 1994, 90, 147-154.

72 A. K. Leuz and C. A. Johnson, Geochim. Cosmochim. Acta, 2005, 69, 1165-1172.

73 Q. Y. Chen, Z. Luo, C. Hills, G. Xue and M. Tyrer, Water Res., 2009, 43, 2605-2614.

74 J. F. Xu, Z. Qu, N. Q. Yan, Y. X. Zhao, X. F. Xu and L. Li, Chem. Eng. J., 2016, 284, 565-570.

75 M. A. Barakat and E. Schmidt, Desalination, 2010, 256, 90-93. 